\title{
Advances and limitations of increasing solar irradiance for concentrating photovoltaics thermal system
}

\author{
Mussad Alzahrani ${ }^{1,2^{*}}$, Katie Shanks ${ }^{1}$, Tapas K Mallick ${ }^{1}$ \\ ${ }^{1}$ Environment and Sustainability Institute, University of Exeter, Penryn Campus, Cornwall TR10 9FE, \\ UK \\ ${ }^{2}$ Mechanical and Energy Engineering Department, Imam Abdulrahman Bin Faisal University, \\ Dammam, 34212, Saudi Arabia \\ * Corresponding author: E-mail: ma778@exeter.ac.uk
}

\begin{abstract}
Concentrating photovoltaic-thermal (CPVT) technology harnesses solar energy by increasing the solar density upon cells using optical concentrators. CPVT systems are the focus of ongoing research and improvements to achieve the highest potential for energy harnessing and utilization. Increasing the concentration ratio for high energy generation raises many advances and limitations in the CPVT design. This article highlights the influence of the temperature with an increasing concentration ratio on CPVT components in terms of single/multi-junction semiconductor materials, primary and secondary optical concentrator materials, and thermal receiver design. To achieve this, the theory of single- and multijunction solar cell electrical characteristics $\left(V_{o c}, I_{s c}, F F\right.$ and $\left.\eta\right)$ is first explained to understand their dependence on the temperature and concentration ratio. An extensive literature review discussing the advantages, disadvantages, and potential of current CPVT research is given. This includes graphical and tabular summaries of many of the various CPVT design performances.
\end{abstract}

In this review, it has been ascertained that higher concentration ratios raise the temperature at which the performance, operation and reliability of CPVT system are affected. Also, this review indicates that the temperature elevation of the CPVT components is significantly impacted by the optical configuration and their material types and reflectance. A thermal receiver is illustrated as three components: solar cell (heat source), heat spreader (substrates) and its different types, and cooling mechanism. In addition, the article addresses the thermomechanical stress created with intensified illumination, especially with secondary optics, where the optical materials and optical tolerance need to be carefully explored. The economic implications of a high concentration ratio level are briefly considered, addressing the reduction in system cost by enhancing the system efficiency. Suggestions are made throughout the review as to possible improvements in system performance.

This review article word count is 7,688 words.

Keywords: Concentrated photovoltaic thermal (CPVT), semiconductor materials, bandgap energy, thermal receiver, optical concentrator and concentration ratio.

\section{Contents}

1. Introduction

2. Electrical and thermal considerations for CPVT system ....................................................... 4

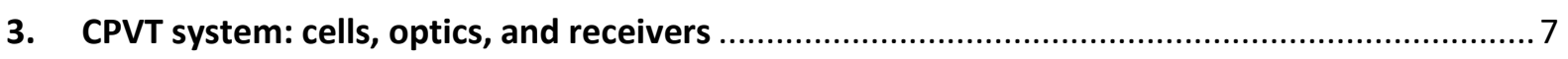

3.1. Semiconductor materials: temperature and efficiencies …................................................... 7

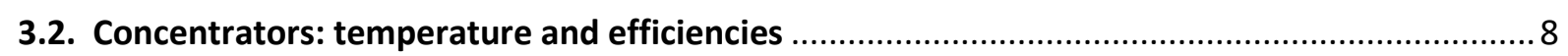




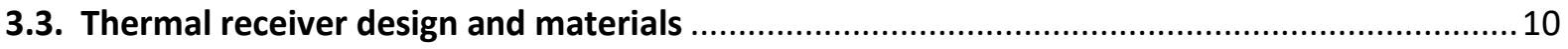

3.4. Linear concentrators: the reflective trough of low-medium concentration

3.5. High concentration point source concentrators and their secondary optics performance ...... 21

3.6. Summary of photovoltaic cell efficiencies and design

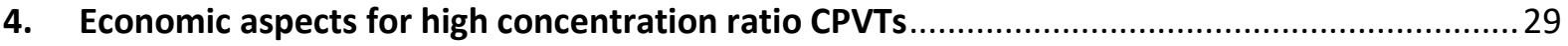

5. Future work

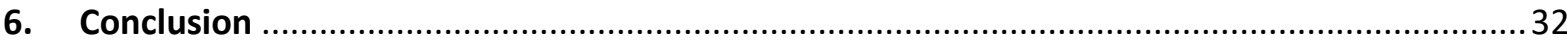

Acknowledgment . .33

Annex.

References

\section{Introduction}

Concentrator photovoltaic thermal (CPVT) systems are the combination of concentrator photovoltaics (CPV) and photovoltaic thermal (PVT) systems. A CPV system concentrates the sun's rays onto a PV cell to generate electricity. A CPVT system concentrates the sun's rays into a fluid to transfer heat either directly or indirectly and to generate electricity. CPV aims to replace the large number of expensive flat PV cells due to its low solar energy density, with inexpensive optical concentrators that concentrate light into fewer PV receivers. However, increasing the solar energy density raises the PV cell temperature and results in increased heat dissipation. High PV cell temperatures impact the designed operating condition of the PV and cause losses in the solar radiation absorbed. Thus, passive or active cooling is needed to maintain the temperature of the PV cell to ensure the highest efficiency. However, cooling down the PV cell temperature causes a parasitic load and this parasitic load increases with increase of the concentration of solar radiation. PVT aims to extract the generated heat and then employ it in the end-use application, such as domestic hot water or direct heating. However, PVT needs to use a large number of PV receivers to produce highquality thermal energy, and that results in high investment costs. Also, the low temperature of the thermal energy limits the possible number of end-use applications.

The drawbacks of both CPV and PVT are resolved in CPVT. CPVT generates both electrical and thermal energies at moderate cell temperatures. Since the cell temperature levels are moderate, high-temperature thermal energy can be extracted and utilized in a vast number of applications. CPVT operates by concentrating the ray optics in a minimal area, which results in a smaller number of PV cells. However, the high concentration in CPVT might result in increased optical losses (e.g. chromatic aberration for lenses), illumination and temperature non-uniformity, and PV overheating. CPVT of more than $>10$ suns (medium and upwards concentration) benefits only from direct solar radiation, not diffuse radiation. The flowchart of the working concept for the CPVT system, including a summary of its limitations, is demonstrated in Fig. 1. 

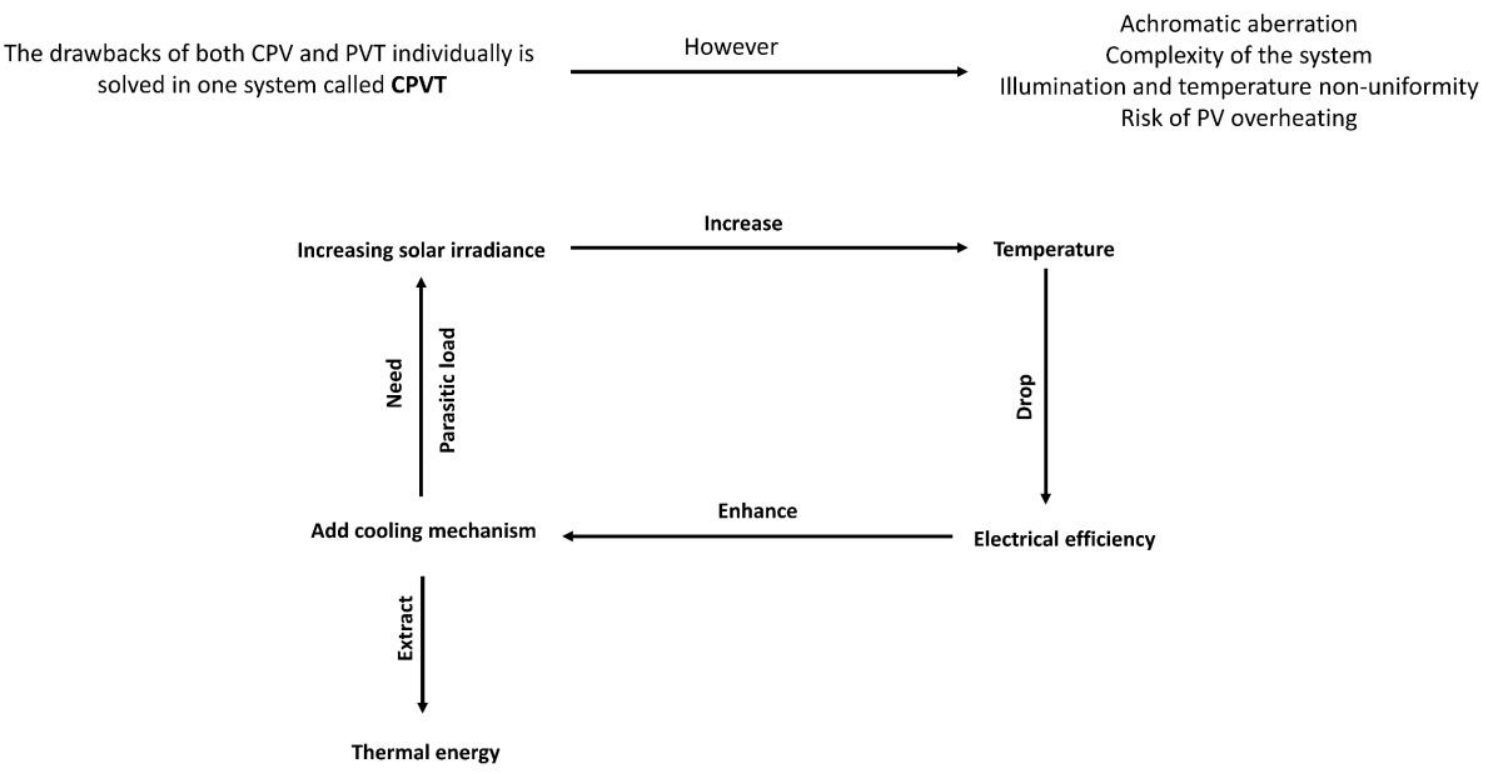

Fig. 1. Working flow of CPVT system with summarized limitations for CPVT system.

The primary component to operate the CPVT system thermally and electrically is the optical performance. Concentrators utilize either imaging or non-imaging optics to intensify the solar density in either one or two optical stages into either a focal line or focal point where electrical and/or thermal energy are captured. The optical performance is dependent on the amount of sunlight incident on the PV cell on the basis of suns, where 1 sun is equivalent to $1000 \mathrm{~W} / \mathrm{m}^{2}$ [1]. Based on the number of concentrated suns, a CPVT system is classified depending on the optical concentration ratio $\left(C R_{I}\right)$, which is the irradiance ratio between the primary optical stage and the receiver. $C R_{I}$ is classified as low $\left(C R_{I}<10 \mathrm{sun}\right)$, medium (10 sun $<C R_{I} \leq 100$ sun $)$, high $\left(100\right.$ sun $<C R_{I} \leq 2000$ sun $)$ or ultrahigh $\left(C R_{I}>\right.$ 2000 sun) [2]. Increasing the $C R_{I}$ results in high thermal and electrical energies; however, a high level of $C R_{I}$ adds to the complexity of the CPVT system, such as the tracking system (acceptance and incident angles) and irradiance non-uniformity on the PV cell.

Different review articles on PVT technology, CPV technology, and CPVT technology can already be found in the literature [3-10]. Sharaf and Orhan [11,12] have primarily focused on CPVT systems in two reviews covering the considerable number of publications on CPVT. Their two publications examined and reviewed the basics and progress in CPVTs, with an exhaustive coverage of all CPVT technology. Daneshazarian et al. [13] reviewed CPVT systems with an emphasis on the fundamentals, operating concept, and system configurations, with the testing results for domestic and industrial applications. Another article by Mojiri et al. [14] provided a review of spectral beam decomposition technologies to evaluate the potential for using this mechanism for solar systems, discussing PVT/CPVT systems, whereas Ju et al. [15] reviewed particularly spectral beam splitting technologies for CPVT systems in a systematic and thorough analysis. However, to the best of the author's knowledge, there has not yet been any review dedicated mainly to assessing the influence of the temperature on the CPVT system components with increase of the concentration ratio.

This literature review therefore aims to investigate the effect of the temperature when increasing the concentration ratio on the CPVT components: solar cell, optics, and 
thermal receiver design, as shown in Fig. 2 (a) and (b). An explanation of the electrical considerations for single- and multi-junction semiconductor materials is given to help understand the influence of the temperature and concentration ratio. One objective of this review is to determine the impact of the temperature in a large number of studies on the semiconductor materials and primary/secondary optics with an increasing concentration ratio in CPVT systems, as well as techniques for thermal management. Only experimental studies that gave all the system details and performance results are reported in order to gain a realistic assessment of achievable performance.
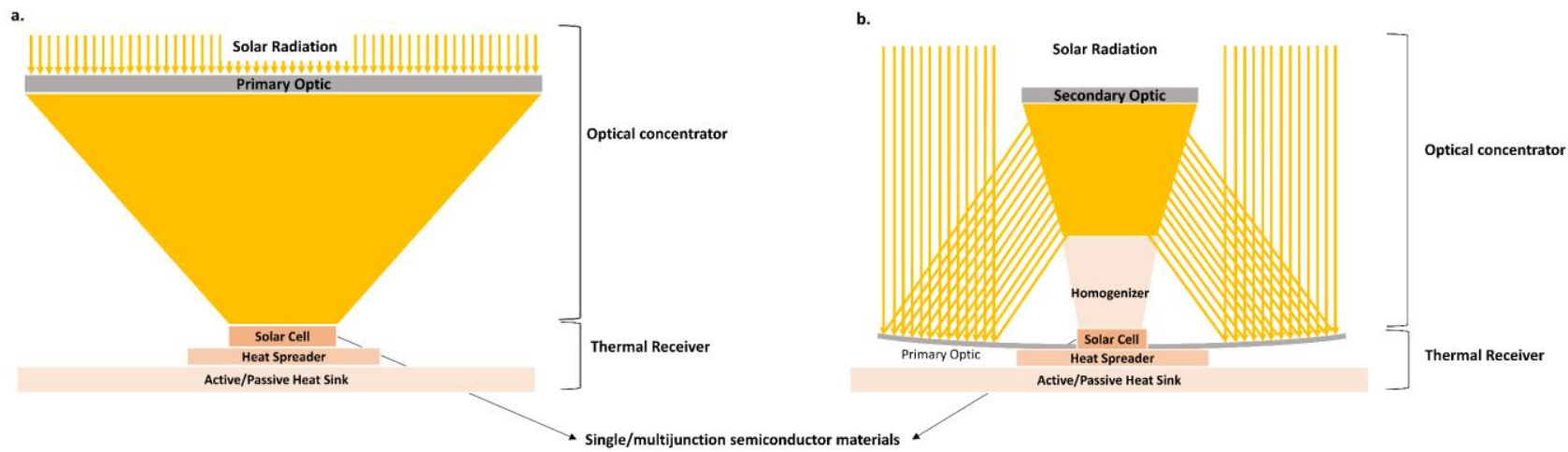

Fig. 2. (a) A basic Fresnel lens and (b) a basic Cassegrain CPVT system configuration for the three components of primary /secondary optics, single-/multi-junction solar cell, and thermal receiver.

\section{Electrical and thermal considerations for CPVT system}

A photovoltaic (PV) cell converts electromagnetic radiation into electrical energy via the $p$ - $n$ junction. The electron absorbs the photon energy in the valence band (n-type semiconductor), and then the absorbed energy stimulates the electron to move to the conduction band ( $p$-type semiconductor). This electron movement creates a hole in the valence band, allowing the free flow of the electron throughout the semiconductor. The PV cell electrical output is challenged by its bandgap energy, in which the photon energy must be greater than the energy of the bandgap to induce photogeneration of the charge carrier (electron and hole). The bandgap energy is the energy separating the valence band from the conduction band. Photon energy that is not compatible with the bandgap energy generates intrinsic losses which can be grouped as thermalization, below bandgap, Boltzmann, Carnot, and emission losses. These intrinsic losses are associated with the limiting of the electrical performance in the form of current and voltage reductions [16]. Below bandgap and emission losses result in current reduction due to the smaller number of charge carriers. In contrast, thermalization, Carnot, and Boltzmann losses result in voltage reduction due to the smaller energy utilization of the charge carrier [17].

The I-V curve of a cell is influenced by both solar irradiance and temperature. The short-circuit current $\left(I_{S C}\right)$ is dependent on its performance on the solar irradiance where $I_{S C}$ and the solar irradiance have a proportional relationship, as in Fig. 3 (a). On the other hand, the open-circuit voltage $\left(V_{o c}\right)$ has an inverse correlation with temperature, as in Fig. 3 (b). The effect of solar irradiance on $V_{o c}$ and the temperature on $I_{S C}$ is minimal. The excellent squareness of the I-V curve (the ratio between the maximum power point (MPP) and $V_{o c}$ and $I_{S c}$ solar cell products) indicates a high Fill Factor (FF) which can be observed at low temperatures or relatively high temperatures (concentrated solar irradiance) but by 
employing the multi-junction solar cell. In terms of high temperature, the squareness of the $\mathrm{I}-\mathrm{V}$ curve is flattened, at which the $F F$ value is low, reflecting a poor quality of PV cell electrical output, especially for a single-junction solar cell. As the concentration ratio is increased, the electrical parameters of the solar cell $V_{o c}, I_{s c}, F F$ and efficiency $(\eta)$ alter; thus, their sensitivity to temperature also changes.

a.

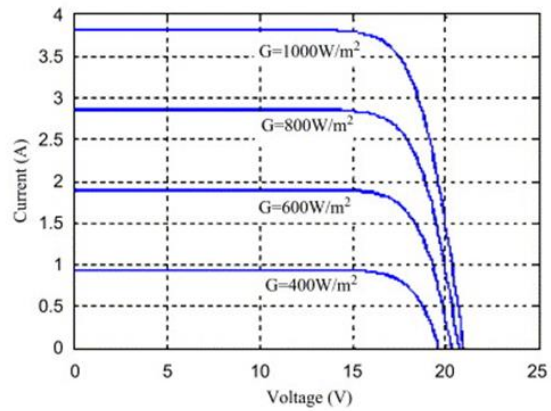

b.

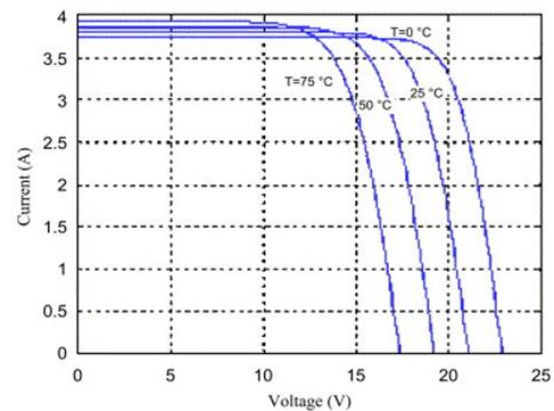

Fig. 3. Effect of (a) solar irradiance and (b) cell temperature on I-V curve of a single-junction PV cell [18].

A multi-junction PV (MJPV) cell allows sorting of the photon energy by adding more than one junction with different bandgap energy to maximize the efficiency of the PV cell and hence the power output [11][12]. The MJPV cell is stacked in series, where $V_{o c}$ is the sum of all the subcells' $V_{o c}$. The temperature coefficient $\Delta V_{o c} / \Delta T$ of the multi-junction is also the sum of the $\Delta V_{o c} / \Delta T$ [19]. The temperature coefficient $\Delta V_{o c} / \Delta T$ of the multi-junction faces a drop in $V_{o c}$ when the number of junctions increases due to the low bandgap energy required for the last subcell. However, increasing the solar irradiance reduces the temperature coefficient drop due to an increase in the $V_{o c}$. The current in the stacked series needs to be matched to avoid losses [19]. Since the temperature coefficient is not equal from the bottom, medial, to top-subcells, the current will be different in each subcell, causing "current mismatch". When the tandem-subcell temperature increases, the bandgap decreases and this results in the increase of the $I_{s c}$. The top subcell bandgap is also decreased, allowing fewer photons to reach the bottom subcell, and this minimizes the $I_{s c}$ with temperature. Additionally, the current output at every subcell has a limitation and this influences the $F F$ of the MJPV cell. Aiken et al. [15] conducted a temperature coefficient study of the integrated current for a triple junction cell InGaP/InGaAs/Ge at a temperature range from $5{ }^{\circ} \mathrm{C}$ to $100{ }^{\circ} \mathrm{C}$. The result indicated that $I_{s c}$ has a current mismatch of only $3.3 \%$ at $100{ }^{\circ} \mathrm{C}$. Thus, a solar cell is negligibly sensitive to temperature in terms of current mismatching.

Solar cell efficiency and bandgap energy are the two main factors for solar cell selection. The maximum efficiency of single-junction solar cells is described by the ShockleyQueisser limit, where all the photons above the bandgap are absorbed, and this limits the maximum conversion efficiency to $33.7 \%$ [20]. The bandgap energy differs according to the energy-band structure of the semiconductor materials. The theoretical maximum efficiency for different single-junction solar cell materials, with their bandgap energy designed as either wafer-based or thin film, is measured in different companies and demonstrated in Fig. 4 $[21,22]$. 


\section{Semiconductor Materials}

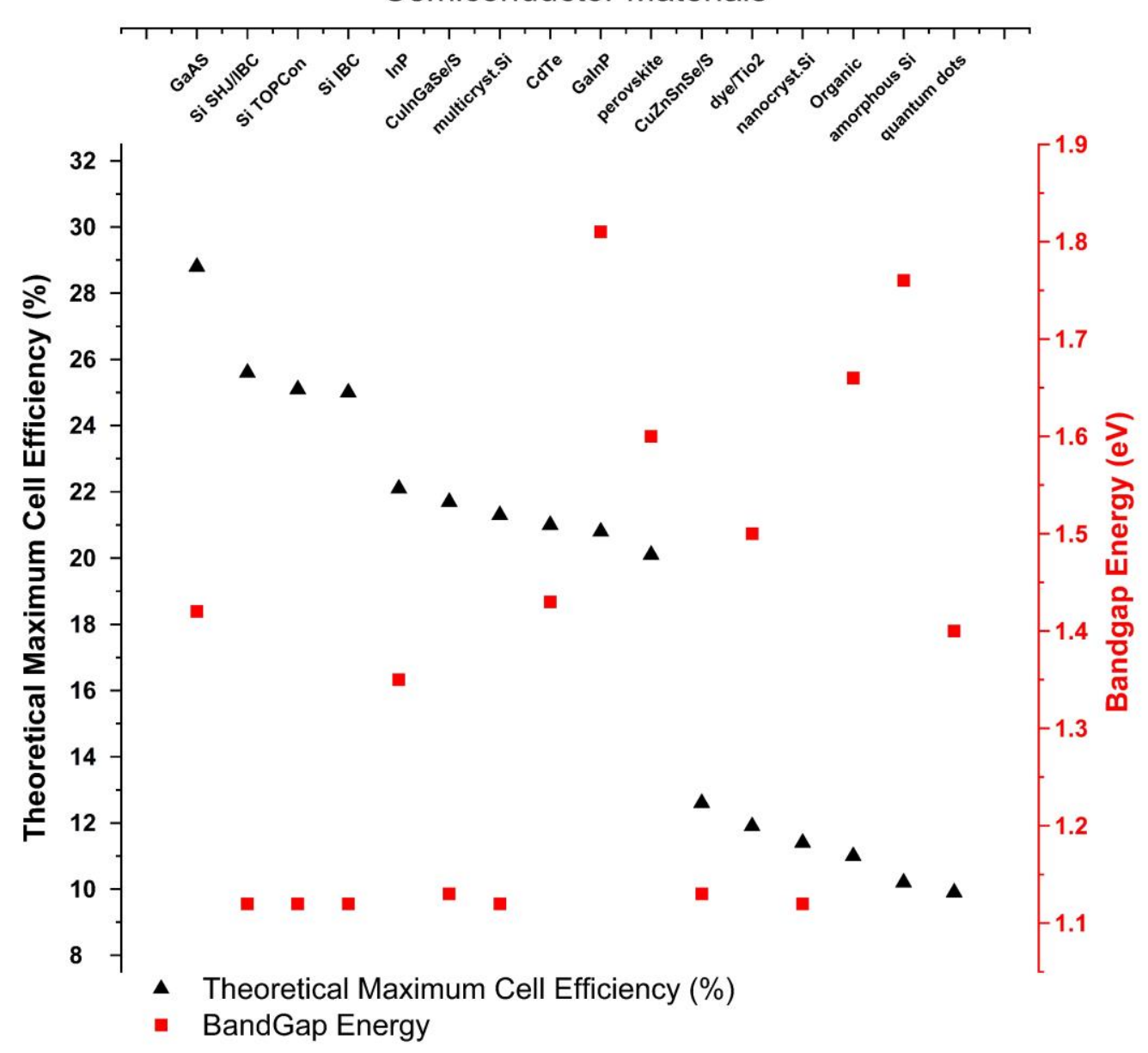

Fig. 4. Different semiconductor materials (thin-film and wafer-based) bandgap energy, maximum efficiency, all under 1 sun concentration ratio. The theoretical maximum cell efficiency is measured for terrestrial application under AM 1.5.

Increasing the number of junctions reduces the thermalization to below the bandgap losses, and this increases the conversion efficiency of the solar cell [17]. A multi-junction solar cell has the capability to absorb a wide range of solar wavelengths due to the different bandgap energy for the individual subcells in one monolithic junction solar cell. The limiting efficiency is illustrated in Fig. 5 for several non-toxic and abundant cell materials made of 1 to 8 junctions for the ideal bandgap. The maximum efficiency of an infinite number of junctions with an optimized bandgap for a blackbody spectrum at $6000 \mathrm{~K}$ under concentration is $86.8 \%$ at AM $1.5[23,24]$; however, current electrical fabrication techniques have only been optimized for up to 5 junctions. Introducing new MJPV cell architectures with different numbers of subcells should not result in any new form of loss or increase the price of electrical fabrication. However, other costs are likely to rise due to the use of rarer and more expensive materials for the multiple layers. 


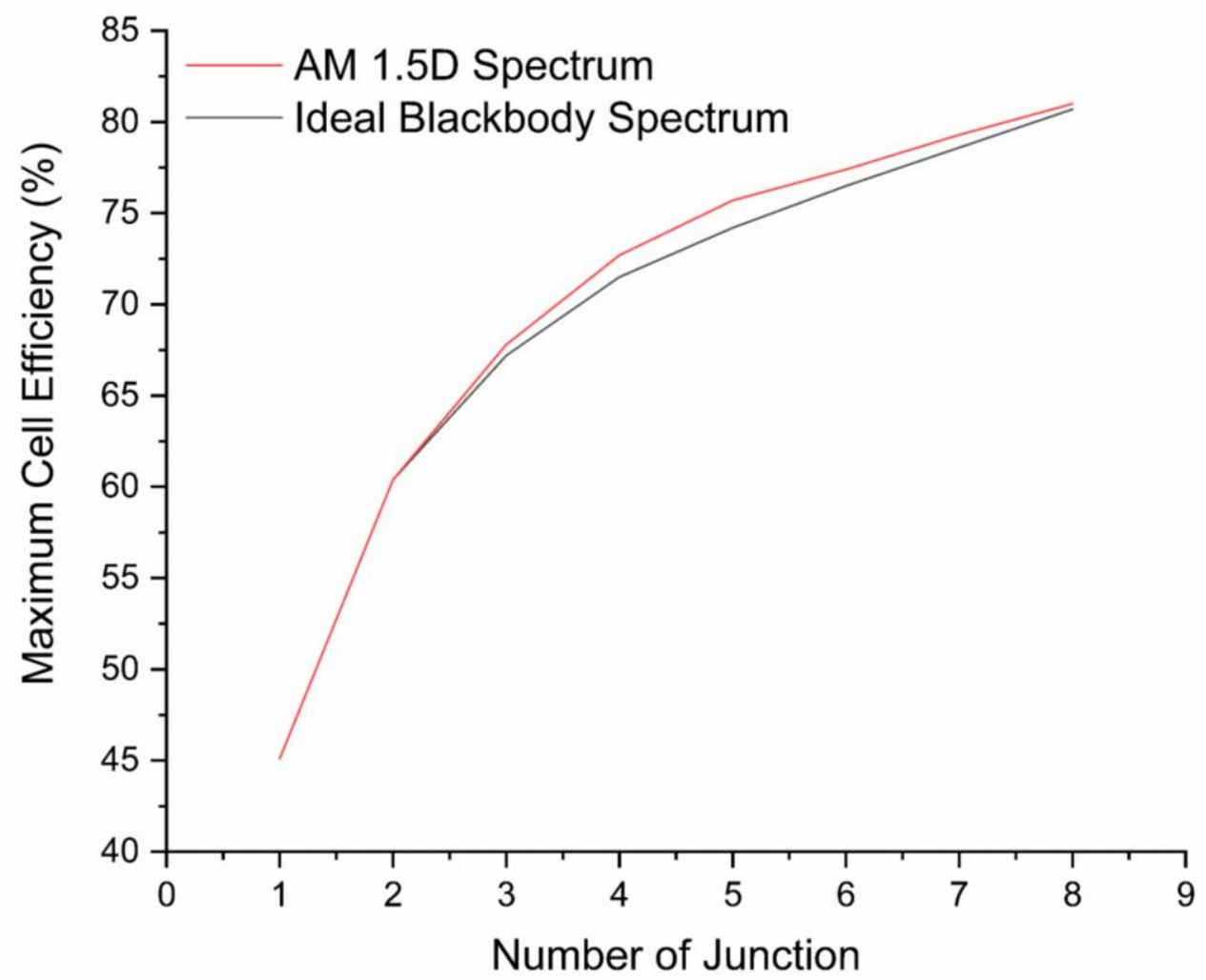

Fig. 5. The limiting efficiency for ideal bandgap energy under no concentration for solar cell use. The solar cells' efficiencies were calculated based on an ideal blackbody spectrum (black line) and the AM 1.5D spectrum (red line) for various semiconductor material configurations.

5

3. CPVT system: cells, optics, and receivers

\subsection{Semiconductor materials: temperature and efficiencies}

Due to the bandgap energy, the unabsorbed photon energy on the solar cell surface is converted to thermal energy, increasing the cell temperature. Moreover, concentrating solar radiation onto a PV cell and solar irradiance non-uniformity also increase the cell temperature and hence reduce the cell efficiency. Other efficiency losses also occur in the PV cell due to poor absorption of photons, such as reflectance loss in the inner and outer layers and shading loss due to the contact grid on the front side of the PV cell. Elevated cell temperatures accelerate cell degradation, thus minimizing their lifetime. To ensure the maximum possible lifetime and an adequate cell efficiency, the cell should be maintained at the typical operating temperature at different ranges of concentration ratio [25].

A large number of semiconductor materials used in different theoretical and experimental studies of solar concentrator systems with their concentration ratio range are collectively shown in Fig. 6. Clearly, gallium arsenide (GaAs) semiconductor material in one-, two- or three-junction configurations can accept a wide range of concentration ratios due to its low temperature sensitivity, high resistivity to radiation damage, and good performance under concentrated illumination. 


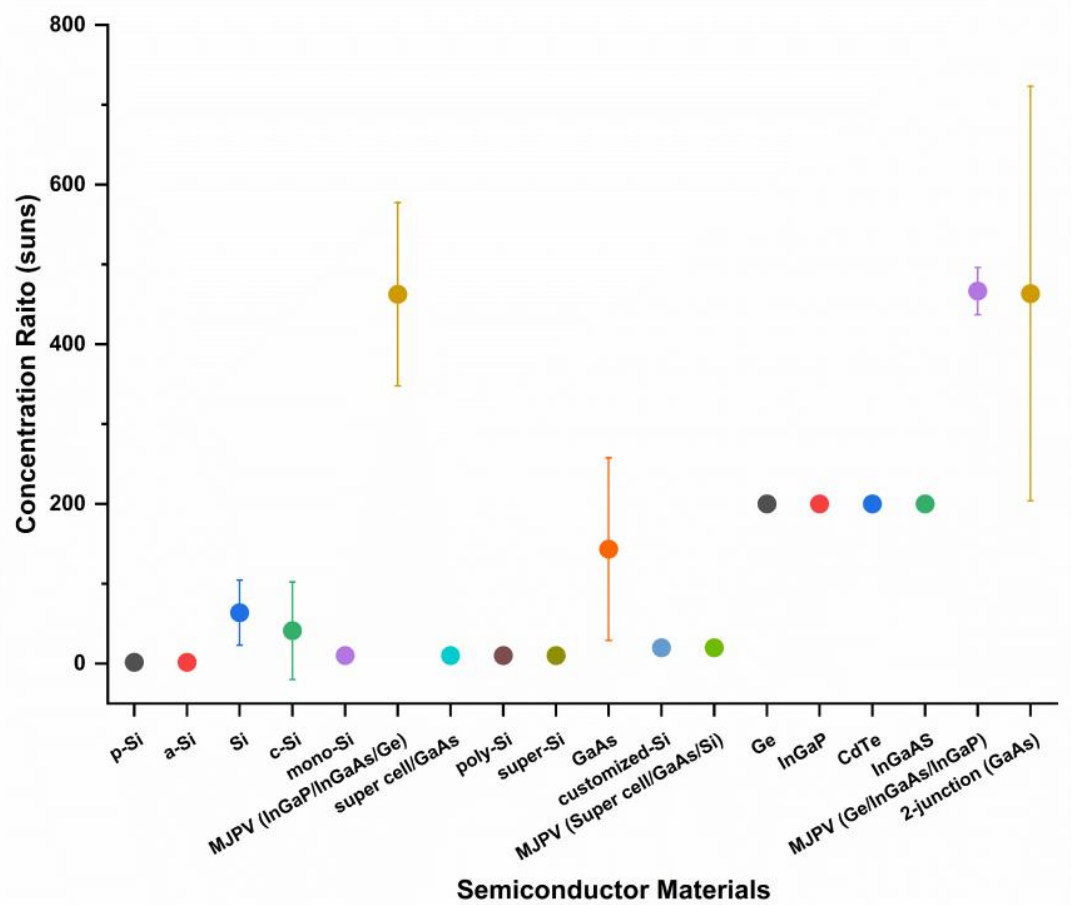

Fig. 6. Semiconductor materials and their concentration ratio in theoretical and experimental studies considered by this review with interval bars which show the range of concentration ratios tested in the literature.

As outlined in Fig. 7, the bandgap of the semiconductor material, the concentration ratio, and thermal properties should be taken into consideration in relation to each other in selecting the PV cell material to avoid operating at a high temperature. PV cell materials are dependent on the cell temperature under concentrated illumination. Thus, the bandgap energy of a PV cell should be selected in accordance with the concentration ratio to enhance the electrical and thermal performance.

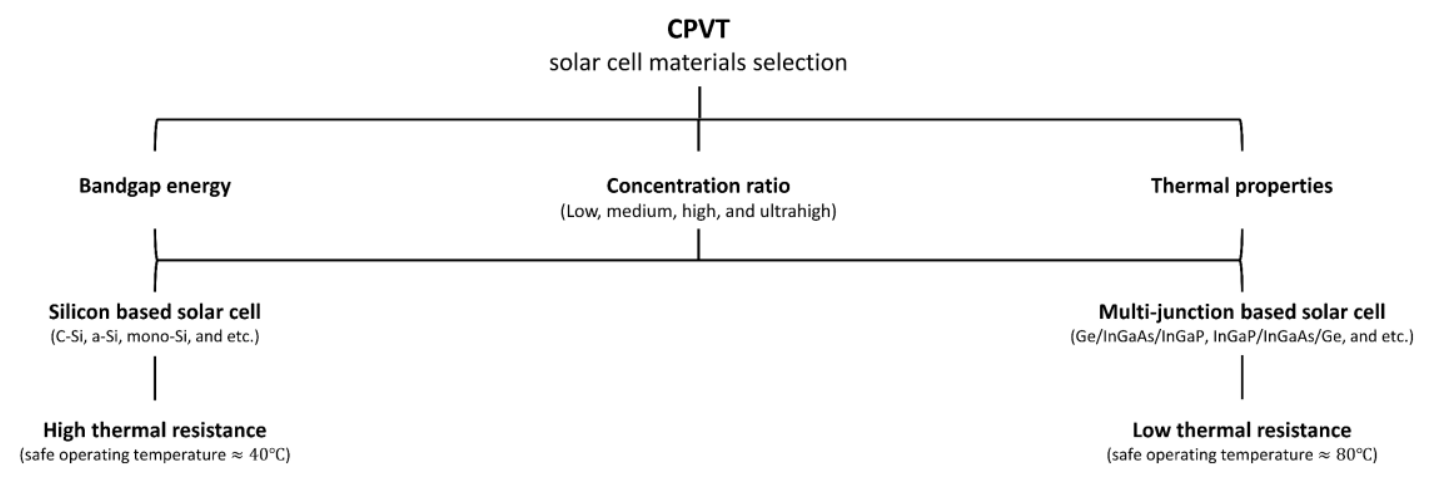

Fig. 7. Factor considerations in the selection of the solar cell materials in a CPVT system.

\subsection{Concentrators: temperature and efficiencies}

The optical tolerance of a CPVT system is a critical factor, especially with increasing concentration ratio and taking into consideration the sunlight divergence angle of \pm 0.265 . The divergence angle of the sunlight implies an equally small acceptance angle, which should be enough to capture the solar radiation emitted from the sun. However, the impact of other factors, such as tracking error, thermomechanical effects, dynamic load, and materials properties, must also be considered [26]. The acceptance angle indicates the required tracking system sensitivity, where the light divergence should be minimized to allow for a high 
concentration ratio. Minimized light divergence is achieved by either a large size primary optic or a secondary optic. To ensure the lowest light divergence, a highly accurate continuous tracking system and a highly smooth surface are required, which are expensive and difficult to acquire. Adding a secondary optic such as a homogenizer or light funnel into the CPVT design improves the acceptance angle and uniformity of the illumination profile of the system, which reduces the demand on the system accuracy. However, the materials of the secondary optics should be carefully selected to withstand the high temperature. In addition, maximizing the size of the primary optics adds to the overall cost of the initial system. The advances and limitations of CPVT optics in terms of increasing the concentration ratio are summarized in Fig. 8.

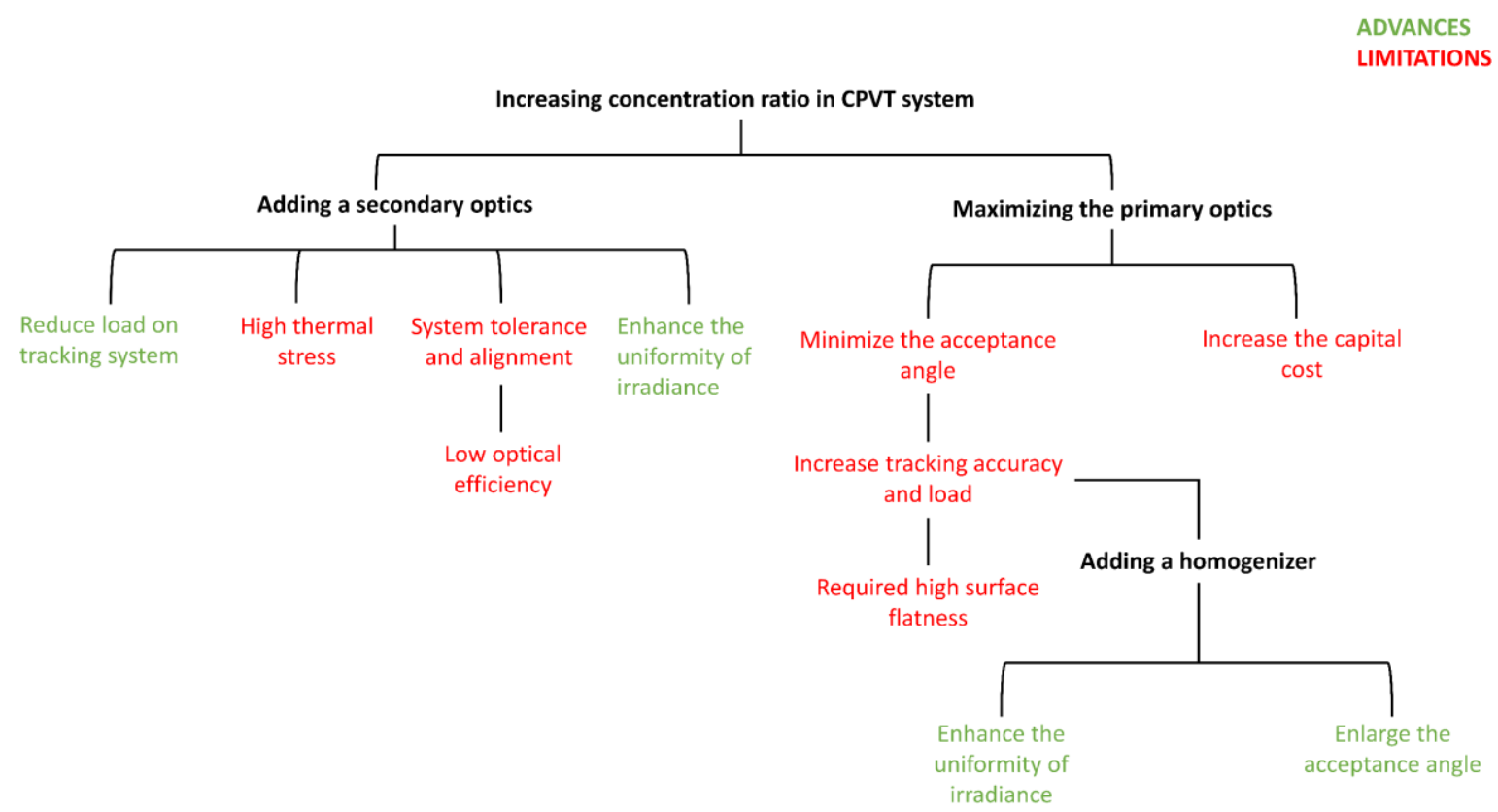

Fig. 8. Summary of advances and limitations in the optical concept for increasing the concentration ratio.

The optical efficiency of a solar concentrator is dependent on the incident angle, where the maximum performance is typically achieved at normal incidence $\left(90^{\circ}\right)$ to the sun (the zenith angle is equal to the system tilt angle). This is when there is the least scattering and absorption within the system, according to the optical properties of the concentrator materials, and where the solar radiation is highly reflected/refracted from the concentrator components. The graph of a low concentration of 3.6 suns crossed compound parabolic concentrator shows a drastic drop in optical efficiency at a $35^{\circ}$ incident angle (the acceptance angle) [27], as shown in Fig. 9 (a). In contrast, the ultrahigh concentration ratio based on the Fresnel lens producing 5247 suns shows a drop of $90 \%$ in the optical efficiency at incidence angles of $0.4^{\circ}$, which confirms the dependency of the optical efficiency on the incident angle and demonstrates the reduction in the required acceptance angle by increasing the concentration ratio beyond 100 suns [28,29], as in Fig. 9 (b). 

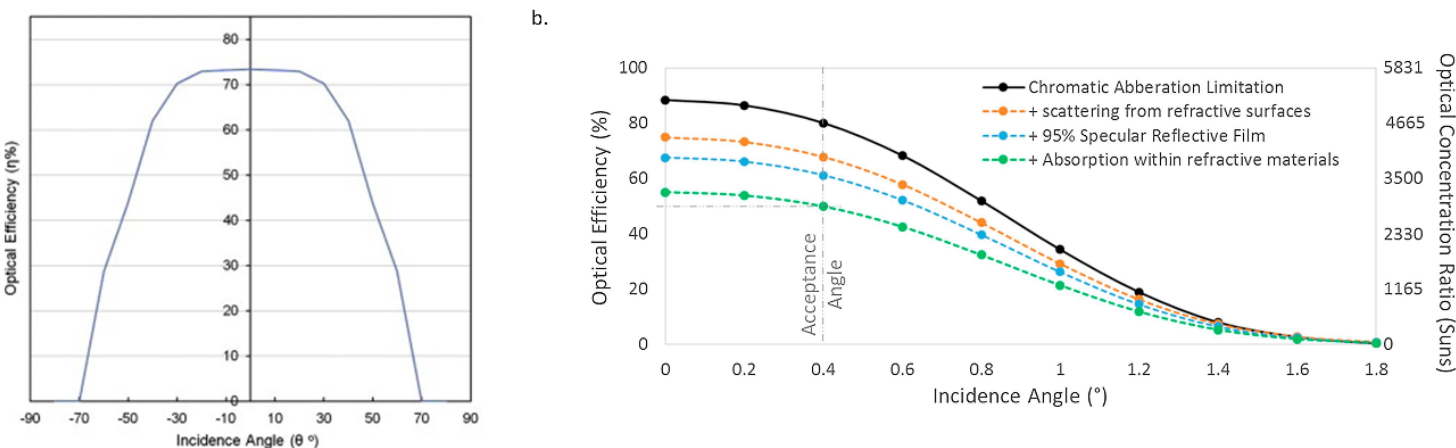

Fig. 9. Optical efficiency vs incidence angle: (a) optical efficiency in CPC for low concentration ratio in building application; (b) optical efficiency in high concentration photovoltaic design based on Fresnel lens $[27,28]$.

The mechanisms of concentrating the solar radiation are reflective, refractive, luminescent, total internal reflection, or a combination of these. Optical concentrators employ multiple stages to increase the acceptance and/or the concentration ratio. Boosting the concentration ratio is achieved at the price of different configurations of CPVT systems. The ranges of concentration ratio and working fluid temperatures for different CPVT systems theoretically and experimentally investigated are illustrated in Fig. 10.

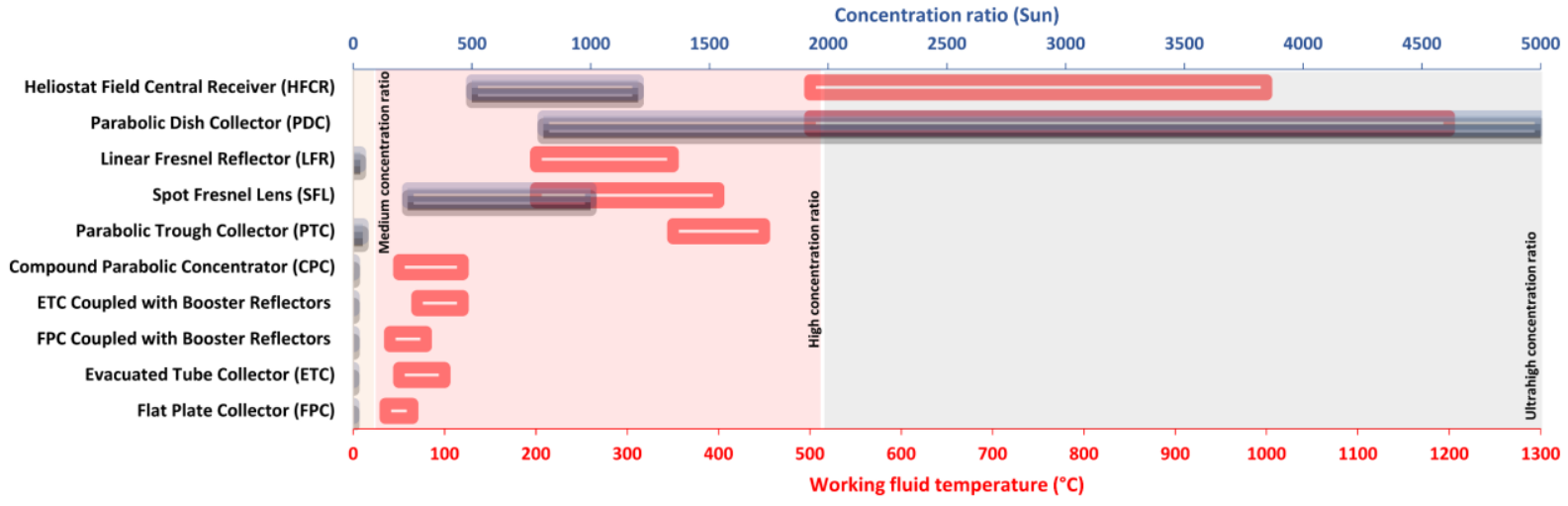

Fig. 10. CPVT systems with the concentration ratio ranges and working fluid temperature ranges as reported in $[11,13]$.

\subsection{Thermal receiver design and materials}

The process of thermally managing the heat in a CPVT system relies on the concept of pre-illumination and post-illumination heat extraction utilizing a heat transfer fluid (HTF). Preillumination design is based on the concept of spectral decomposition, allowing a higher outlet temperature by redirecting all the unutilized spectral wavelength to a thermal receiver $[14,15]$. However, the difficulty of matching the optical properties with either the HTF or the filters means that pre-illumination design is less mature than post-illumination design. Postillumination design harvests the heat after reaching the solar cell. However, the outlet HTF temperature is limited to the cell's maximum recommended operating condition in the range of $50-80^{\circ} \mathrm{C}$.

The thermal performance of the PV cell primarily relies on the heat spreader and the accompanying different layers of the materials employed. The heat spreader is located between the PV cell (heat source) and the cooling mechanism to conduct heat for thermal utilization according to the temperature range or dissipation rate. The most common heat spreaders in CPVT systems are direct bonded copper (DBC) and insulated metal substrates (IMS) due to their excellent thermophysical properties [30-32]. However, silicon wafer substrates have shown a high potential as heat spreaders due to their thermal expansion compatibility with silicon semiconductor materials [33]. The heat spreader materials need to 
have a high thermal conductivity and high electrical insulation, where doubling the thermal conductivity of the heat spreader enhances the thermal efficiency by $13.5 \%$ [34]. In addition, increasing the contact factor between different layers using thermal paste results in conducting much of the heat to the thermal collector, reducing in this way the cell efficiency by just $-0.0043 \% /{ }^{\circ} \mathrm{C}$, whereas without thermal paste the result is $-0.0094 \% /{ }^{\circ} \mathrm{C}$ [35]. High resistance silica gel is widely used in CPVT systems as electrical insulators, having high thermal conductivity [36-38].

Cooling mechanisms (post-illumination) for the PV cell may be passive or active. Passive cooling in point focus systems has been proven to successfully manage the PV cell temperature with different heatsink geometries and for high concentration ratios for up to 2000 suns [35,39]. For ultrahigh concentration ratios, solar cells of $1 \mathrm{~mm}^{2}$ or smaller can maintain the cell temperature below the maximum recommended operating temperature with a conventional flat-plate heatsink up to 10,000 suns [40]. In passive cooling, the heat dissipation is attributed to the cell area, where the heat is generated. Thus, maximizing the area of the heatsink by exploring different geometry configurations would maximize the heat dissipation rate. For the heatsink material, silicon has shown the lowest thermal stress and the maximum heat transfer in comparison with aluminum and copper [33]. In $>2000$ suns, the weight of the heatsink should be considered to reduce the required dynamic load and avoid increased tracking error.

Active cooling, which ordinarily embraces forced motion for a cooling fluid, increases the overall thermal efficiency. An active cooling mechanism is widely used in systems with line focus PV cell design, where a line pipe configuration is more suitable to extract heat effectively. Pure fluid or nanofluid cooling is more suitable than air due to its high heat capacity and its potential for different end-use applications, especially with high temperature. The originality of using nanoparticles with the fluid is to enhance the thermal conductivity, in this way boosting the heat transfer between the receiver and the fluid. However, increasing the temperature of the nanoparticles has a major influence on improving the thermal conductivity [41-45]. The parasitic power for a fan or pump increases with the increase in the concentration ratio, where more fluid needs to be forced onto the heat dissipation domain at an optimized rate for the maximum heat extraction.

\subsection{Linear concentrators: the reflective trough of low-medium concentration}

Most CPVT designs are linear geometry systems made of reflective materials, typically in a trough shape and capable of up to 100 suns (medium concentration). M. Li et al. [46] studied the electrical and thermal performance of $2 \mathrm{~m}^{2}$ and $10 \mathrm{~m}^{2}$ configurations for an aluminum alloy parabolic trough at 10.27 suns and 20 suns, respectively. In the $2 \mathrm{~m}^{2}$ system, arrays of cells using four types of semiconductor materials connected in series were mounted on the receiver using a thermally-conductive tape. In the $10 \mathrm{~m}^{2}$ configuration, the width of the receiver and the width of the aperture area were increased, resulting in an increase of the concentration ratio. Water circulated as HTF to cool down the cell temperature. The experimental results of the different semiconductor materials are listed in Table 1. 


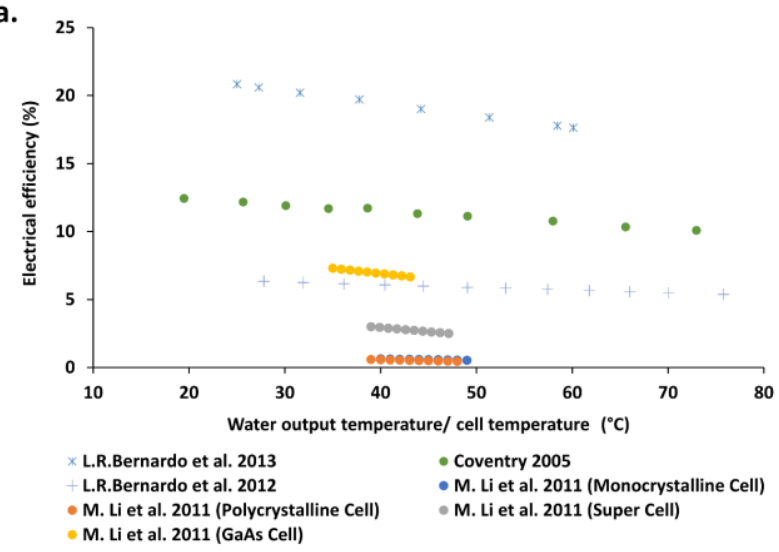

b.

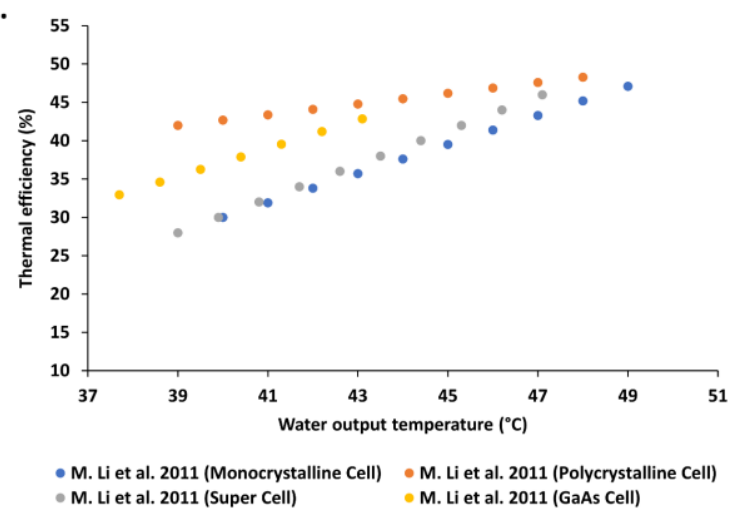

Fig. 11. The water output temperature/cell temperature impact on (a) the electrical efficiency and (b) the thermal efficiency of the system in different studies [46-49].

Table 1 The parameters of the $2 \mathrm{~m}^{2}$ and $10 \mathrm{~m}^{2}$ trough parabolic configuration [46]

\begin{tabular}{lllll}
$\begin{array}{l}\text { Semiconductor } \\
\text { materials }\end{array}$ & $\begin{array}{l}\text { Number of cells } \\
\text { in an array }\end{array}$ & $\begin{array}{l}\text { Water output temperature } \\
\left({ }^{\circ} \mathbf{C}\right)\end{array}$ & $\begin{array}{l}\text { Thermal } \\
\text { efficiency (\%) }\end{array}$ & $\begin{array}{l}\text { Electrical } \\
\text { efficiency (\%) }\end{array}$ \\
\hline Apertures area $\mathbf{2} \mathbf{~ m}^{\mathbf{2}}$ & & \\
\hline Monocrystalline cell & 10 & $40-49$ & $30-47$ & $0.53-0.63$ \\
Polycrystalline cell & 10 & $39-48$ & $42-48$ & $0.44-0.59$ \\
Super cell & 16 & $39-47$ & $36-46$ & $2.50-3.00$ \\
GaAs cell & 40 & $35-43$ & $28-43$ & $6.67-7.31$ \\
\hline & & Apertures area $\mathbf{1 0} \mathbf{~ m}^{\mathbf{2}}$ & & 7.51 \\
\hline Concentrating silicon cell & 96 & 29.60 & 42.41 & 9.88 \\
GaAs cell & 40 & 33.89 & 49.84 &
\end{tabular}

The water output temperature can be an indication of the cell temperature, which is higher for cells with higher series resistance and hence typically reduced power outputs. The best performance of GaAs is mainly due to its lower series resistance and yet it still has a higher performance in a higher temperature environment. However, the high series resistance for mono-Si, poly-Si and super cells (made from silicon and GaAs material) indicates better thermal performance [46]. Reduction in the concentration ratio results in a decrease in the heat exchange effectiveness. Thus, the PV temperature increases due to less heat being removed, which reduces the electrical efficiency. $M$. Li et al. [46] demonstrate the correlation between the rise in the water output temperature and the thermal efficiency, and the reverse correlation between the water output temperature and the electrical efficiency for an aperture area of $2 \mathrm{~m}^{2}$, as in Fig. 11 (b). Kunnemeyer et al. [50] investigated a V-trough concentrating model theoretically and experimentally for 1.6 suns. The concentrators were constructed from mirror-finished stainless steel sheet to withstand the corrosive maritime climate in New Zealand. The polished stainless steel in [51] had a reflectivity of 0.67 . However, aluminum with 0.9 reflectivity would yield a higher solar irradiance at the absorber surface. The combined electrical and thermal efficiency peaked at 35\%, even though the system was designed to achieve a peak efficiency of $70 \%$. The drop in efficiency is due to heat loss by convection and radiation in the absence of a glazing layer, which reduced the thermal efficiency. Even with the low reflectivity, the stainless-steel sheet offered a $25 \%$ increase in the concentration ratio over a year in comparison to aluminum. Kostic et al. [52] presented the influence of the aluminum (Al) sheet and aluminum foil reflectance for flat plate solar 
radiation concentrators. The outcomes showed that the total and diffuse reflectance of the Al sheet and Al foil concentrators are the same, whereas the specular reflectance is higher for Al foil concentrators, resulting in increasing the solar radiation intensity. The solar radiation intensity results in a daily increase of the electrical and thermal efficiency, as shown in Table 2.

Table 2 Results for solar radiation intensity, thermal energy generated, and electrical energy generated

\begin{tabular}{llll} 
Reflectors & $\begin{array}{l}\text { Concentration ratio } \\
\text { (sun) }\end{array}$ & $\begin{array}{l}\text { Daily thermal energy } \\
\text { generated (\%) }\end{array}$ & $\begin{array}{l}\text { Daily electrical energy } \\
\text { generated (\%) }\end{array}$ \\
\hline Al sheet & 1.44 & 39 & 8.6 \\
Al foil & 1.66 & 55 & 17.1
\end{tabular}

7 Although with a $10 \%$ additional cost of $\mathrm{Al}$ sheet and $\mathrm{Al}$ foil concentrators, the results 8 demonstrated a remarkable increase in the energy efficiency of $35 \%$ and $50 \%$ for concentrators made of $\mathrm{Al}$ sheet and Al foil, respectively, in comparison to the system without concentrators. Nilsson et al. [53] studied the long-term performance of an asymmetric compound parabolic concentrator (CPC) built for high altitude in Sweden. Anodized aluminum and aluminum-laminated steel reflectors were investigated. The aluminum-laminated steel reflectors were the preferable option due to their improved mechanical properties which require less mechanical support. However, the steel-based reflector has a relatively low specular reflectance because its plastic coating absorbs light below $400 \mathrm{~nm}$ and silicon cells absorb from $\sim 300 \mathrm{~nm}$. The measurement of the MaReCo (Maximum Reflector Collector) in these studies showed that the front reflector collects most of the solar radiation in the summer, whereas the back reflector dominated collection in the spring and fall, as shown in Fig. 12. The comparison of the electrical output results showed a $49 \%$ increase for the front collector and $23 \%$ increase for the back reflector for both materials compared with no reflector. Steel placed in the back reflector is a good option since there is no difference in the yearly output power for the two materials. For maximum utilization of the solar radiation, PV cells should be installed on both sides of the receiver. Another study showed a compound parabolic concentrator (CPC) of anodized aluminum with $95 \%$ solar reflection resulting in 1.5 suns. The study demonstrated that the PV cell can still reach a high temperature even with a low concentration ratio, where the electrical efficiency was measured to be $20.9 \%$ at $25{ }^{\circ} \mathrm{C}$ [47]. The dependency of the electrical efficiency on the cell temperature is $-0.4 \% / K$, as illustrated in Fig. 11 (a) [47]. The temperature of the outlet water was measured to show the impact of the temperature on the electrical efficiency. 
MaReCo, MaximumReflectorCollector

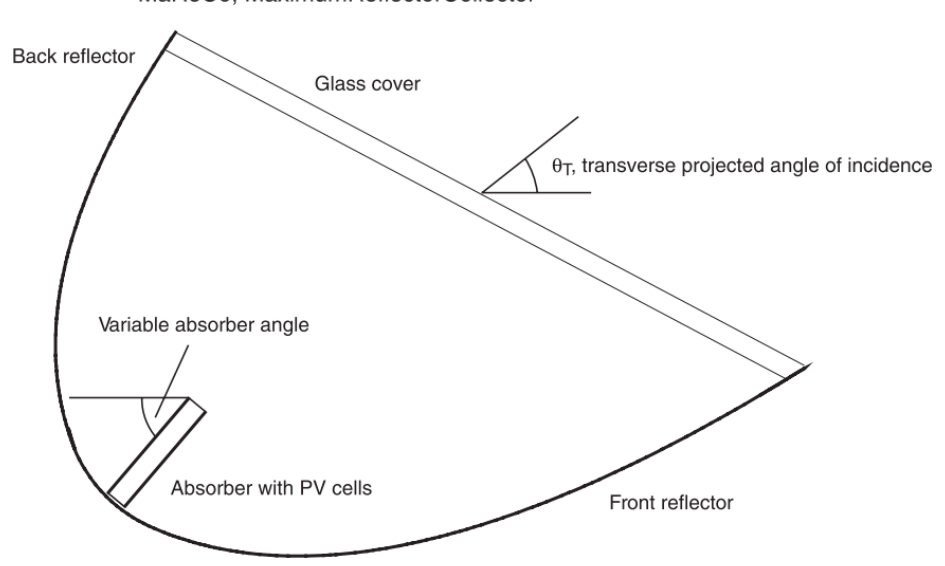

Fig. 12. MaReCo (maximum reflector collector) PV-thermal hybrid has the same focal line for both parabolic reflectors. The glass cover is tilted at a $30^{\circ}$ angle between the absorber and the horizontal. Also shown is the transverse projected angle of incidence[53].

Coventry [48] investigated a parabolic trough collector with a concentration ratio of 35 suns. The collector consists of a glass-on-metal mirror that focuses illumination into a monocrystalline silicon solar cell for electricity and thermal generation. The electrical and thermal efficiency was measured to be $11 \%$ and $58 \%$ at standard operating condition (ambient temperature of $25{ }^{\circ} \mathrm{C}$ and direct radiation of $1000 \mathrm{~W} / \mathrm{m}^{2}$ ), respectively. Also, the impact of non-uniform illumination on the PV cell was investigated. The illumination along the length of the trough showed a remarkable variation due to the mirror shape, the gap between mirrors, and shading by the receiver support. This investigation included measurement for the non-uniform illumination for 30 suns and 90 suns for the entire and the middle third of the cell surface. A reduction in open circuit voltage of $6.5 \mathrm{mV}$ results in an electrical efficiency drop of $20.6 \%$ for uniform illumination and of $19.4 \%$ for centralized illumination, as shown in Fig. 13. Consequently, non-uniform illumination causes a locally overheated spot on the PV cell area, which might result in reducing the cell lifetime, although this has still not yet been experimentally investigated. The magnitude of the voltage drops due to the locally overheated spot is significant.

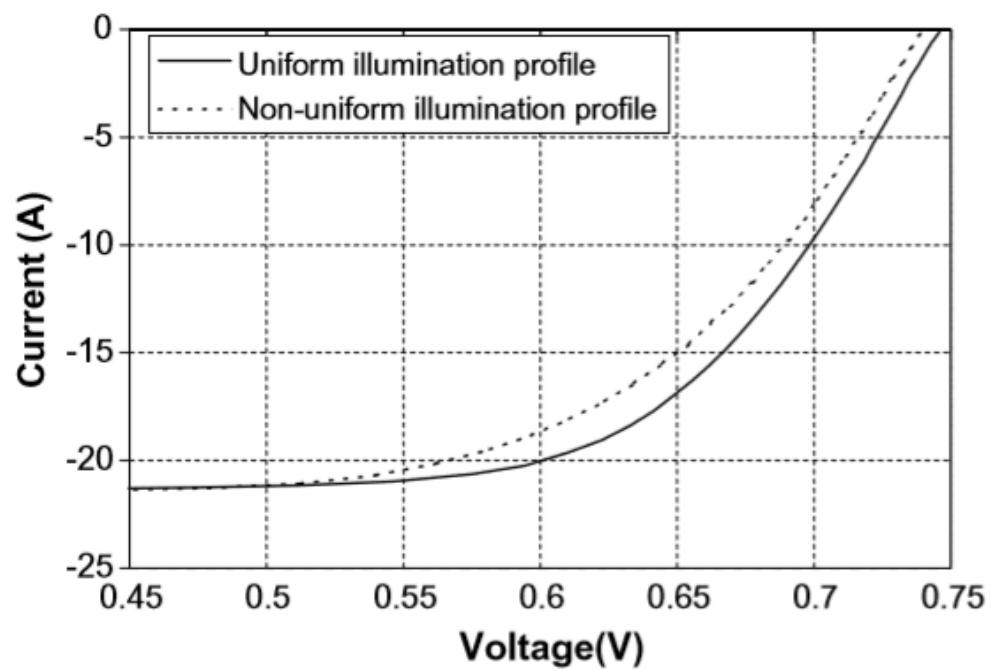

Fig. 13. I-V curve for uniform illumination over the whole cell area (30 suns) and non-uniform illumination on the middle third of the cell (90 suns) [48].

The dependency of the electrical efficiency on the cell temperature is $-0.35 \% /{ }^{\circ} \mathrm{C}$, as shown in

Fig. 11 (a) [52]. Tripanagnostopoulos et al. [54] determined the optimum operation of the 
hybrid system for a pc-Si module with different scenarios of additional glazing (glass sheet), a booster reflector (aluminum sheet), or both, aiming to maximize the total energy output with a circulating fluid (air/water). The additional glazing is intended to increase the thermal output of the system to about $30 \%$, but that results in high optical losses, reducing the electrical efficiency by $16 \%$. The drop in electrical efficiency is balanced by the integration of the diffuse booster reflector, increasing the electrical and thermal efficiencies by about $16 \%$ and $45 \%$, respectively. The aluminum sheet results in increasing the solar radiation by $50 \%$; thus, the electrical efficiency increased from $25 \%$ to $35 \%$ at PV temperatures varying between $40-70{ }^{\circ} \mathrm{C}$. Also, the electrical efficiency was measured for the uninsulated and insulated back surface to be $13.3 \%$ and $3.3 \%$, respectively. With the insulated back surface, less convection and radiation raised the cell temperature to $55^{\circ} \mathrm{C}$; however, for the uninsulated back surface, the PV cell temperature is $43^{\circ} \mathrm{C}$. Bernardo et al. [49] evaluated the performance of a parabolic trough at a low concentration ratio of 7.8 suns. The selected optical material was silver-coated plastic film laminated on a steel sheet with a reflectance factor of $90 \%$ and a cover glass with a transmittance of $90 \%$. The electrical efficiency was measured to be $6.7 \%$ at $25{ }^{\circ} \mathrm{C}$. The electrical and thermal dependency on the water outlet temperature is illustrated in Fig. 11 (a) [49], representing the electrical efficiency calculated as a function of different working temperatures at beam irradiation higher than $900 \mathrm{~W} / \mathrm{m}^{2}$.

$\mathrm{Xu}$ et al. [55] studied a low concentrator parabolic collector of 2.44 suns coupled with a refrigeration cycle. The output electrical efficiency was $17.5 \%$ with mirror-finished aluminum sheet optical concentrators whose total reflectance was $88 \%$. The condenser was capable of raising the water temperature from $30^{\circ} \mathrm{C}$ to $70{ }^{\circ} \mathrm{C}$. Davidsson et al. [56] utilized a buildingintegrated multifunctional PVT solar window where the reflectors were anodized aluminum with antireflective low-iron glazing. The antireflective material increased the transmittance by about $5 \%$ in [57] to achieve a concentration ratio of 1.33 suns. Anodized aluminum $[47,49,56,58-60]$ as an optical material is highly desirable for optical concentrators in parabolic trough systems due to its high reflectance. Aluminum reflects well for $200-400 \mathrm{~nm}$ ultraviolet and 3000-10000 nm infrared [61]. However, aluminum [62] has a lower reflectance in the visible region between 700-3000 nm near-infrared compared to copper, gold and silver. Since aluminum reacts with air to create an oxidization layer, anodization as a common electrochemical process is needed to grow a protective oxide film on the aluminum metal surface to improve protection and durability.

For refractive materials, PMMA (methyl methacrylate) $[38,58,63]$ is the dominant material used most commonly in Fresnel lens systems due to its high transparency and excellent stability in different weather conditions up to $85^{\circ} \mathrm{C}$ [64]. Spectral color dispersion in a PMMA Fresnel lens system relies on the refractive index of the lens materials in the range of 1.515 to 1.470 between blue and red light. The dependence of the reflective index on the temperature, humidity and incident angle is minimal for PMMA Fresnel lens materials. For low and medium concentration ratios, a trough-based CPVT system is commonly a linear-focal design with reflective materials, whereas refractive lens is utilized more in the point source system and secondary optics to achieve a high concentration ratio. For the comparison and understanding of the optical materials discussed above, the optical materials with lowmedium concentration ratios discussed in this section are summarized, along with their thermal properties (coefficient of thermal expansion and working temperature) and remarks for every study, in Table 3. 


\begin{tabular}{|c|c|c|c|c|c|c|c|}
\hline & Reference & $\begin{array}{c}\text { Concentration } \\
\text { Ratio (suns) }\end{array}$ & Optics Configuration & Primary Optics Material & $\begin{array}{l}\text { Coefficient of Thermal } \\
\text { Expansion }\left(\mathrm{m} / \mathrm{m}^{\circ} \mathrm{C}\right)\end{array}$ & $\begin{array}{c}\text { Working } \\
\text { Temperature } \\
\left({ }^{\circ} \mathrm{C}\right)\end{array}$ & Remarks \\
\hline \multirow{3}{*}{ 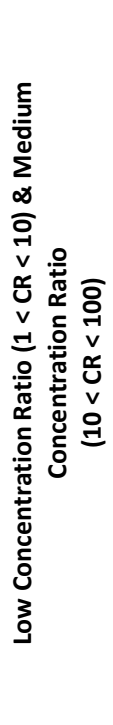 } & [38] & 5.85 & Linear Fresnel lens & PMMA & \multirow{3}{*}{$0.000077[65]$} & \multirow{3}{*}{$-40-85$ [65] } & $\begin{array}{l}\text { - Experimental performance evaluation of pure } \\
\text { thermal and integrated PV/T solar system } \\
\text { using linear Fresnel lens. } \\
\text { - Reduction in electrical efficiency from } 10.9 \% \text { to } \\
7.63 \% \text { due to solar concentration. } \\
\text { - Power output increases by about } 28 \% \text {. }\end{array}$ \\
\hline & [63] & 17 & Domed linear Fresnel lens & PMMA & & & $\begin{array}{l}\text { - Theoretical and experimental performance } \\
\text { assessment of Idhelio CPV-T module based on } \\
\text { curved Fresnel lens. } \\
\text { - The overall electrical and thermal efficiencies } \\
\text { were evaluated to compare with targeted } \\
\text { performance. } \\
\text { - Theoretical and measured optical efficiency } \\
\text { found to be } 80 \% \text { and } 77 \% \text {, respectively. }\end{array}$ \\
\hline & [58] & 25 & Linear Fresnel lens & PMMA & & & $\begin{array}{l}\text { - Experimental performance of solar } \\
\text { greenhouse reflects near-infrared radiation } \\
\text { (NIR) to improve the climate condition in the } \\
\text { greenhouse. } \\
\text { - Reflected NIR results in electrical and thermal } \\
\text { production utilizing PV/T collector module. }\end{array}$ \\
\hline
\end{tabular}




\begin{tabular}{|c|c|c|c|c|c|c|}
\hline [62] & 0.8 & Flat reflector & Aluminum & \multirow{3}{*}{$0.0000267[66]$} & \multirow{3}{*}{ Up to $298-932$ [66] } & $\begin{array}{l}\text { - Performance characteristics of finned } \\
\text { passive PV/T system combining PV panel } \\
\text { with a solar water heater for heat and } \\
\text { electrical generation. } \\
\text { - Two removable reflectors were integrated } \\
\text { on the collector to increase the total solar } \\
\text { irradiance and to save extra sensible } \\
\text { thermal energy }\end{array}$ \\
\hline [60] & 80 & Parabolic dish & Aluminum with protective coating & & & $\begin{array}{l}\text { - Two-stage parabolic dish with spectral } \\
\text { beam splitting technology. } \\
\text { - Spectral beam-splitting reduced the cell } \\
\text { temperature and increased the cell } \\
\text { conversion efficiency. }\end{array}$ \\
\hline [67] & 1.5 & Flat reflector & Aluminum sheet & & & $\begin{array}{l}\text { - Thermal and electrical efficiencies of PV/T } \\
\text { collector with and without reflector have } \\
\text { been determined in an optimal position. } \\
\text { - Additional cost of about } 10 \% \text { considering } \\
\text { reflectors made of aluminum sheet. } \\
\text { - Aluminum reflectors resulted in energy gain } \\
\text { in the range of } 20.5 \% \text { to } 35.7 \% \text { during } \\
\text { summer. }\end{array}$ \\
\hline [54] & 1.35 & Flat reflector & Diffused aluminum plate & $0.000014[68]$ & $550-600[69]$ & $\begin{array}{l}\text { Hybrid PV/T experimentally studied } \\
\text { outdoors benefiting from air and water to } \\
\text { extract heat. } \\
\text { Glazing is used to increase the thermal } \\
\text { output, and a diffuse booster reflector is } \\
\text { used to increase solar irradiance density. }\end{array}$ \\
\hline [52] & 1.5 & Flat reflector & Aluminum foil & $0.0000257[70]$ & $260-510[71][72]$ & $\begin{array}{l}\text { - Energy efficiency of PV/T collector is } \\
\text { studied for aluminum foil reflector. } \\
\text { - Energy generated by PV/T collector made } \\
\text { of Al foil was higher than the Al sheet due } \\
\text { to higher specular reflectance. }\end{array}$ \\
\hline [46] & 10.27 & Parabolic trough & Aluminum alloy & $0.0000248[66]$ & $298-780[66]$ & $\begin{array}{l}\text { - The experimental performance analysis and } \\
\text { optimization of } 2 \mathrm{~m}^{2} \text { and } 10 \mathrm{~m}^{2} \mathrm{TCPV} / \mathrm{T} \\
\text { system is investigated for different solar cell } \\
\text { materials. } \\
\text { - Increasing the width of the reflector mirror } \\
\text { and decreasing the width of the focal line } \\
\text { resulted in increasing the energy flux on the } \\
\text { receiver. }\end{array}$ \\
\hline
\end{tabular}




\begin{tabular}{|c|c|c|c|c|c|c|}
\hline [53] & 3.5 & CPC & $\begin{array}{l}\text { Anodized aluminum and aluminum- } \\
\text { laminated steel }\end{array}$ & & & $\begin{array}{l}\text { - Estimates the annual electrical and thermal } \\
\text { energy from MaReCo hybrid system in } \\
\text { Lund, Sweden. } \\
\text { - Front-side positioning of the cell was better } \\
\text { than back-side, but the optimum design } \\
\text { was to have cells on both sides. } \\
\text { - Anodized aluminum and aluminum- } \\
\text { laminated steel did not influence the power } \\
\text { output. }\end{array}$ \\
\hline [75] & 4 & CPC & Anodized aluminum & & & $\begin{array}{l}\text { - PV/T system cooled by water in Alvkarleby, } \\
\text { Sweden, was investigated. } \\
\text { - Optical efficiency measurements of glazing, } \\
\text { reflectors, and PV solar cell determined to } \\
\text { be } 71 \% \text {. } \\
\text { - Anti-reflection treated glazing increased } \\
\text { electrical power further. }\end{array}$ \\
\hline [47] & 1.5 & CPC & Anodized aluminum & $0.000013[73]$ & Up to $80[74]$ & $\begin{array}{l}\text { - The electrical performance variations of an } \\
\text { asymmetrical PV/T CPC-collector } \\
\text { considering reflector edges, sharp } \\
\text { acceptance angles and bypass diodes were } \\
\text { studied over a short incidence angle. } \\
\text { - The focus was to achieve a high-resolution } \\
\text { incident angle. } \\
\text { - Diffuse radiation to the total power was } \\
\text { considered. }\end{array}$ \\
\hline [56] & 1.33 & Parabolic reflector & Anodized aluminum & & & $\begin{array}{l}\text { - PV/T collector for building applications to } \\
\text { decrease the overall cost of the PV and } \\
\text { thermal system. } \\
\text { Tiltable reflectors are used to direct solar } \\
\text { irradiance into the PV cell, reducing the } \\
\text { thermal loss through windows. }\end{array}$ \\
\hline [59] & 15 & Linear Fresnel reflector & Anodized aluminum & & & $\begin{array}{l}\text { Micro hybrid concentrators were developed } \\
\text { for urban rooftop application in Australian } \\
\text { National University. } \\
\text { - The preliminary results showed electrical } \\
\text { power and thermal power of more than } 300 \\
\text { W and } 1500 \mathrm{~W} \text {, respectively. } \\
\text { - One sub-module in every receiver showed } \\
\text { non-operational mode due to not } \\
\text { optimizing the incident angle, reducing } \\
\text { electrical power by } 10 \% \text {. }\end{array}$ \\
\hline
\end{tabular}




\begin{tabular}{|c|c|c|c|c|c|c|}
\hline [55] & 2.44 & CPC & Mirror-finished aluminum sheet & $0.000023[76]$ & 2072 [77] & $\begin{array}{l}\text { - LCPV/T-HP system to generate both } \\
\text { electricity and heat output. } \\
\text { - Heat output is used to run a refrigerant } \\
\text { (R134a) cycle. } \\
\text { - The system gave an average coefficient of } \\
\text { performance (COP) of } 4.8 \text { during summer } \\
\text { times. }\end{array}$ \\
\hline [51] & 14.5 & CPC & Stainless steel & $0.000008[66]$ & Up to 1800 [78] & $\begin{array}{l}\text { - LCPVT systems were tested during spring } \\
\text { time in Tunisian Sahara. } \\
\text { - Two mass flowrates were tested in the } \\
\text { system } \dot{m}=0.01871 / s \text { and } \dot{m}=0.051 / s \text {. } \\
\text { - } \dot{m}=0.01871 / s \text { resulted in higher thermal } \\
\text { efficiency. }\end{array}$ \\
\hline [49] & 7.8 & Parabolic trough & $\begin{array}{l}\text { Silver-coated plastic film laminated on a } \\
\text { steel sheet }\end{array}$ & $0.0000168[78]$ & $650[78]$ & $\begin{array}{l}\text { - PV/T hybrid system investigated in } \\
\text { simulation for different geographic } \\
\text { locations. } \\
\text { - The experimental comparison was made } \\
\text { between the hybrid and conventional } \\
\text { design. } \\
\text { - The PV/T hybrid system showed an } \\
\text { electrical efficiency of } 6.4 \% \text { at optical } \\
\text { efficiency of } 45 \% \text {. } \\
\text { - The results of the hybrid system were poor } \\
\text { in comparison with the conventional } \\
\text { system due to the difficulties in } \\
\text { concentrating solar irradiance. }\end{array}$ \\
\hline [50] & 1.6 & V-trough & Mirror-finished stainless steel & $0.000496[66]$ & $298-1673[66]$ & $\begin{array}{l}\text { - V-trough PV/T system with active cooling } \\
\text { improved the electrical output of the } \\
\text { system. } \\
\text { - The durability of stainless steel is higher } \\
\text { than the reflective aluminum concentrator. } \\
\text { - This system design needs further } \\
\text { modifications for reducing heat losses by } \\
\text { either enhanced cooling methodology or } \\
\text { higher thermal efficiency. }\end{array}$ \\
\hline
\end{tabular}




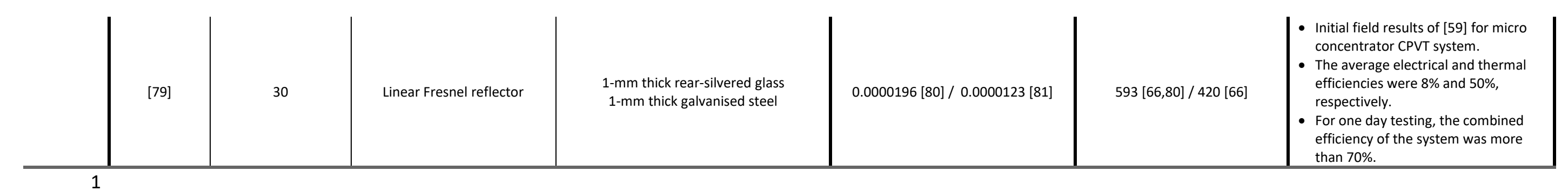




\subsection{High concentration point source concentrators and their secondary optics performance}

In a high concentration photovoltaic system, the optical materials and optical tolerance need to be carefully investigated and designed. Secondary optics are introduced to bring the concentration to the required value and relax the demand on the system accuracy. The integration of a homogenizer in the optical configuration allows the system to minimize the non-uniformity of the solar irradiance and increase the acceptance angle. However, thermo-mechanical stresses as a result of non-uniformity could damage the optical materials. Thus, the secondary optics and homogenizer materials need to be thermally stable and durable, with low thermal expansion coefficients and high working temperatures. Al Siyabi et al. [82] investigated the effects on one unit of a $3 \times 3$ concentrator prototype producing 200 suns of concentration ratio on $\mathrm{K} 9$ glass and crystal resin homogenizers which were refractive truncated pyramid designs (RTP-homogenizer). The in-house test showed that the K9 glass homogenizer was $20 \%$ more optically efficient than the crystal resin counterpart, although this translated into only a $5 \%$ improvement in the electrical efficiency when comparing the K9 glass homogenizer to the crystal resin homogenizer. However, both improved the electrical performance of the CPV system by $27 \%$ and $23 \%$ respectively in comparison to the system without secondary optics. Also, this study reported the degradation on the top surface of the crystal resin homogenizer, which starts melting at a high concentration ratio. An elevated temperature on the optical materials stimulates their thermal expansion and thereby decreases their reflectivity and can change the shape of the optics, which is one of the causes of illumination non-uniformity. Sarwar et al. [83] studied the effect of temperature and solar irradiance on the thermal performance and optical properties on unpolished 304/304L stainless steel using a sun simulator. The material was tested under five different levels of uniform illumination ranging between $579.3 \mathrm{~kW} / \mathrm{m}^{2}$ and $917.1 \mathrm{~kW} / \mathrm{m}^{2}$ for 17 and 50 minutes, respectively. The results showed that the material's thermal performance decreases with increase of the solar irradiance. However, the drop in the thermal performance is dependent on the material temperature, which was tested between $557 \mathrm{~K}$ and $368 \mathrm{~K}$. When the material temperature dropped by $159 \mathrm{~K}$ the thermal performance fell to $21 \%$, and when the material temperature dropped by $22 \mathrm{~K}$ the thermal performance declined to $6.7 \%$. Also, the study highlighted the impact of temperature on the optical performance, where the reflectance of the material changed by $26 \%$ and $7 \%$ at the temperatures of $557 \mathrm{~K}$ and $368 \mathrm{~K}$, respectively. Another study by McVey-White et al. [84] discussed the effect of the lens temperature on the illumination uniformity of three Fresnel-based configurations where the concentration ratio exceeded 500 suns. The three configurations were silicon-on-glass primary with no secondary, PMMA primary with truncated inverted pyramid secondary, and a PMMA 4-quadrant Fresnel-Köhler configuration. The performance of the optical lens for the three configurations was measured at 25 to $50{ }^{\circ} \mathrm{C}$. The silicon-on-glass primary with no secondary showed a $12.4 \%$ increase in the total amount of solar irradiance up to a temperature of $30{ }^{\circ} \mathrm{C}$, and then a drop of $81.2 \%$ in the total irradiance as the temperature reached $50{ }^{\circ} \mathrm{C}$. Up to $40{ }^{\circ} \mathrm{C}$, the PMMA primary with truncated inverted pyramid secondary showed uniformity in the solar irradiance across the lens; however, a further temperature rise showed an increase in the irradiance and a drop in the uniformity. Compared with the silicon-on-glass primary with no secondary, the PMMA primary with truncated inverted pyramid secondary showed an increase of $8.5 \%$ in the total amount of solar irradiance uniformity at $25^{\circ} \mathrm{C}$. Shanks et al. [85] reported the temperature and solar misalignment 
effects on the optical materials within a 200 suns conjugate refractive-reflective homogenizer (CRRH) based on a Cassegrain design. The system was made up of a low-iron glass cover, a plastic substrate primary with a vapor-deposited reflective coating, and a Sylguard 184 refractive secondary optic supported by an ABSplus-P430 plastic casing. The full design was tested in a vacuum drying oven for 3 hours at setpoint temperatures of 60,70 , and $80{ }^{\circ} \mathrm{C}$, where no deformation was observed. The Sylguard homogenizer bulk had an operating temperature from $-45^{\circ} \mathrm{C}$ to $200{ }^{\circ} \mathrm{C}$, but the support structure underwent heat deflection at $96{ }^{\circ} \mathrm{C}$ under 66 psi. Due to sun misalignment, the sun focused on the ABSplus-P430 homogenizer support structure and caused melting. The focal area of concentrated light was measured to be at a temperature of $149{ }^{\circ} \mathrm{C}$ with ventilation (no system walls) and $226.3^{\circ} \mathrm{C}$ without air ventilation (with enclosure walls in place), which is far higher than its operating temperature. Also, the measured temperature of the central MJPV cell varied in the range of 43-48 ${ }^{\circ} \mathrm{C}$ for no walls and $54-61{ }^{\circ} \mathrm{C}$ with walls. However, the electrical and thermal performance needs to be investigated to identify the overall efficiency with this level of concentration ratio. Vincenzi et al. [86] investigated a novel configuration of 400 suns based on Cassegrain optics. The optical materials were: polycarbonate coated with PVD metallization in aluminum as a primary optic; BK-7 optical glass coated with an aluminum layer and silicon oxide protection as a secondary optic; and highly reflective Alanod MIRO as a homogenizer. The maximum efficiency of MJPV was measured to be $29 \%$ at mid-afternoon with a corresponding cell temperature of $70{ }^{\circ} \mathrm{C}$. Even with a high concentration ratio, the author did not report any thermoplastic defects for the optical concentrators, which indicates the robustness of the designed dual-axis solar tracking system, where its angular acceptance is $\pm 0.6^{\circ}$. Colozza et al. [87] designed a small Cassegrain system of 3000 suns to melt lunar regolith simulant. The primary and optics were made of aluminum and were coated with vacuum-deposited chrome, silver, and protective silicon dioxide ( $\mathrm{SiO}$ ). Since aluminum has a poor surface finish, a silver coating was proposed for both optics, and this resulted in an optical efficiency of $90 \%$. The silver coating gave a $5 \%$ increase in the reflectivity. However, the silver coating's durability and secondary lifetime is a major concern compared to aluminum. Also, the mechanical surface finishing and precision of the optics is an additional cost in the overall system expense. When the mirrored surfaces operated at less than $10 \%$, the concentrator achieved a temperature of $415^{\circ} \mathrm{C}$ at the receiver. The author stated that by minimizing the solar cell to one half, the geometrical concentration ratio can reach 6000 suns. A unique design was proposed by Chayet et al. [88] of a dish parabolic concentrator consisting of a flat mirror placed on a plastic parabolic surface molded into a global parabolic shape. The system was designed to achieve a concentration ratio of 629 suns with a $21 \%$ and $50 \%$ electrical and thermal efficiency, respectively. This system has the capacity to produce hot water in the range of $60-90{ }^{\circ} \mathrm{C}$. Kribus et al. [89] studied the performance of a 500 -sun parabolic dish design. The parabolic dish is made of glass back-coated with silver to produce the reflectivity, and externally coated with a protective coating to protect the silver from environmental exposure. The system achieved electrical and thermal efficiencies of $60 \%$ and $20 \%$, respectively. The system generated water at $58^{\circ} \mathrm{C}$, where the cell efficiency of the Azur Space MJPV cell was $32 \%$ and its maximum operating temperature $100^{\circ} \mathrm{C}$. To assist with the comparison and understanding of the optical materials discussed above, the secondary optical designs and materials investigated within the literature reviewed here are summarized in Table 4. 


\begin{tabular}{|c|c|c|c|c|c|c|c|}
\hline \multirow{2}{*}{\multicolumn{2}{|c|}{ Reference }} & \multirow{3}{*}{ Concentration ratio (suns) } & \multirow{3}{*}{ Optics configuration } & \multicolumn{3}{|c|}{ Optics material } & \multirow{3}{*}{ Remarks } \\
\hline & & & & \multicolumn{3}{|c|}{ 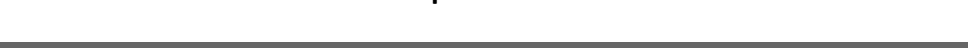 } & \\
\hline & & & & Primary & Secondary & Homogenizer & \\
\hline \multirow{4}{*}{ 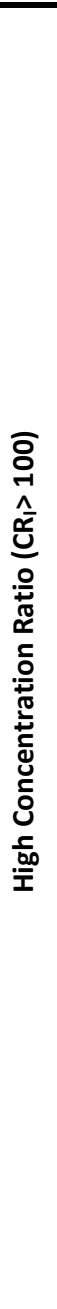 } & [85] & 200 & CRRH Cassegrain & $\begin{array}{l}\text { Plastic with a low-iron } \\
\text { glass cover }\end{array}$ & $\begin{array}{l}\text { Plastic with a low-iron } \\
\text { glass cover }\end{array}$ & $\begin{array}{l}\text { Sylguard with support } \\
\text { structure from ABSplus- } \\
\text { P430 }\end{array}$ & $\begin{array}{l}\text { Reflective refractive homogenizer } \\
\text { tested with Cassegrain design } \\
\text { increased power output by } 7.76 \% \\
\text { compared to theoretical. } \\
\text { At different incidence angle, } \\
\text { experimental results showed } \\
4.5 \% \text { increase in power output in } \\
\text { comparison with purely } \\
\text { refractive homogenizer. }\end{array}$ \\
\hline & [87] & 300 & CRRH Cassegrain & $\begin{array}{l}\text { Aluminum coated with } \\
\text { vacuum-deposited } \\
\text { chrome, silver, and } \\
\text { protective silicon dioxide }\end{array}$ & $\begin{array}{l}\text { Aluminum coated with } \\
\text { vacuum-deposited } \\
\text { chrome, silver, and } \\
\text { protective silicon dioxide }\end{array}$ & - & $\begin{array}{l}\text { The concentration ratio achieved } \\
\text { was significantly lower than the } \\
\text { target. } \\
\text { The deterioration of silver } \\
\text { coating affected the reflectivity } \\
\text { of its surface. } \\
\text { The focal spot was Gaussian } \\
\text { distribution, maximum power at } \\
\text { the center of the focal point. }\end{array}$ \\
\hline & [90] & 550 & Spot Fresnel lens & PMMA & - & $\begin{array}{l}\text { Refractive truncated } \\
\text { pyramids }\end{array}$ & $\begin{array}{l}\text { Optimizing the inverter size for } \\
\text { the maximum energy yield to } \\
\text { attain the typical efficiency curve } \\
\text { for low-, medium-, and high } \\
\text { efficiency inverter. } \\
\text { - The optimum inverter size ratio } \\
\text { differed between } 0.84 \text { and } 1.12 \text {. } \\
\text { The optimum inverter sizing } \\
\text { ratio increases as DNI increases } \\
\text { and inverter efficiency } \\
\text { decreases. }\end{array}$ \\
\hline & [91] & 208.6 & Spot Fresnel lens & PMMA & Kaleidoscope & - & $\begin{array}{l}\text { CPVT system was analyzed } \\
\text { experimentally and theoretically } \\
\text { to assess the electrical } \\
\text { performance, the concentration } \\
\text { ratio, the cell temperature in } \\
\text { different working conditions, and } \\
\text { working fluid temperature. } \\
\text { For a module of } 60 \text { cells, the } \\
\text { daily electrical production on a }\end{array}$ \\
\hline
\end{tabular}




\begin{tabular}{|c|c|c|c|c|c|c|}
\hline & & & & & & $\begin{array}{l}\text { sunny day and cloudy day is } 686 \\
\text { Wh and } 541 \mathrm{~W} \text {, respectively. }\end{array}$ \\
\hline [86] & 400 & Cassegrain & $\begin{array}{l}\text { Polycarbonate coated with } \\
\text { PVD metallization in } \\
\text { aluminium }\end{array}$ & $\begin{array}{l}\text { BK-7 optical glass coated } \\
\text { with an aluminum layer } \\
\text { and silicon oxide } \\
\text { protection }\end{array}$ & Alanod MIRO & $\begin{array}{l}\text { HCPV system designed to be } \\
\text { suitable for implementing both } \\
\text { multi-junction and spectrum- } \\
\text { splitting configurations. } \\
\text { Outdoor characterization of the } \\
\text { two receivers' configurations } \\
\text { showed a low overall efficiency } \\
\text { of } 23 \% \text { for the spectrum-splitting } \\
\text { due to the short wavelength } \\
\text { band ( } 400-1200 \text { nm) in } \\
\text { comparison with multi-junction } \\
\text { solar cell. }\end{array}$ \\
\hline [88] & 629 & Parabolic dish & $\begin{array}{l}\text { Flat mirrors mounted on a } \\
\text { plastic parabolic surface }\end{array}$ & - & - & $\begin{array}{l}\text { - The dish design resulted in } 2.3 \\
\text { kWp electrical and } 5.5 \mathrm{kWp} \\
\text { thermal power per dish. } \\
\text { The output temperature was } \\
\text { dependent on the flow rate and } \\
\text { it was high enough for domestic } \\
\text { applications. }\end{array}$ \\
\hline [89] & 500 & Parabolic dish & $\begin{array}{l}\text { Low-iron glass with a silver } \\
\text { back-coating }\end{array}$ & - & & $\begin{array}{l}\text { - CPVT system is designed for } \\
\text { rooftop use producing } 140-180 \\
\mathrm{~W}\left(20 \% \text { at } 588^{\circ} \mathrm{C}\right) \text { o electricity } \\
\text { and } 400-500 \mathrm{~W}\left(60 \% \text { at } 58^{\circ} \mathrm{C}\right) \text { of } \\
\text { heat. } \\
\text { The wide range of temperatures } \\
\text { allows different applications, } \\
\text { such as cooling processes, water } \\
\text { desalination, and industrial } \\
\text { processes. }\end{array}$ \\
\hline
\end{tabular}


A large number of researchers have explored different semiconductor materials of 3 single-/multi-junction PV cells and demonstrated the effect on the cell efficiency, cell 4 temperature and thermal and electrical efficiency under a wide range of concentration ratios 5 in CPVT systems, as reported above. The PV design is not within the scope of this literature 6 review as it has been thoroughly researched in different articles [11,92,93]. However, a 7 summary of the different PV performance and characteristics has been provided in Table 5 as 8 an essential consideration in CPVT design (as discussed in section 3.1), specifically for the 9 studies where the cell temperature, electrical and thermal efficiency were reported. 
Table 5 Experimental CPVT studies covered in this review article

\begin{tabular}{|c|c|c|c|c|c|c|c|}
\hline Reference & Method & CRı & $\begin{array}{l}\text { Thermal } \\
\text { efficiency }\end{array}$ & Cell materials & $\begin{array}{l}\text { Cell } \\
\text { temperature } \\
\left({ }^{\circ} \mathrm{C}\right)\end{array}$ & Design & $\begin{array}{l}\text { Electrical } \\
\text { efficiency }\end{array}$ \\
\hline [54] & \multirow{18}{*}{ 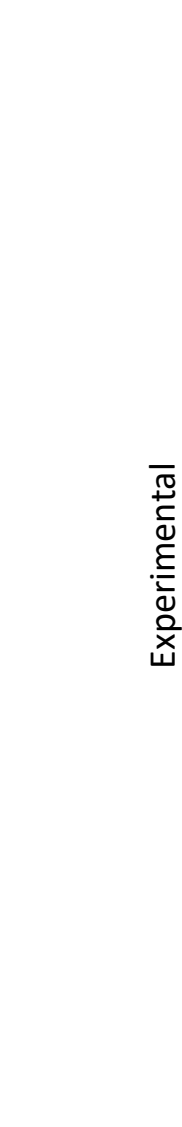 } & 1.35 & $70 \%$ & pc-Si, a-Si & - & PV panel & $13 \%$ \\
\hline [32] & & 1.5 & $15 \%$ & c-Si & 55.6 & Linear & $15 \%$ \\
\hline [47] & & 1.5 & - & $\mathrm{Si}$ & - & Double-sided PV & $10 \%$ \\
\hline [50] & & 1.6 & overall 35\% & $\mathrm{Si}$ & - & Linear & $1 \%$ \\
\hline [94] & & 1.86 & above $50 \%$ & $\mathrm{c}-\mathrm{Si}$ & 87.7 & Linear & $9 \%$ \\
\hline [95] & & 5.2 & $39.40 \%$ & - & - & Linear & $14.10 \%$ \\
\hline [38] & & 5.85 & 46.6 & mono-Si & 20 & Linear & $7.63 \%$ \\
\hline [49] & & 7.8 & $45 \%$ & mono-Si & - & $\begin{array}{l}\text { Linear on two sides } \\
\text { of triangular design }\end{array}$ & $6.40 \%$ \\
\hline [96] & & $5.81-7.1$ & $12.55 \%$ & $\mathrm{c}-\mathrm{Si}, \mathrm{pc}-\mathrm{Si}$ & - & Linear & $12.50 \%$ \\
\hline [59] & & 15 & $60 \%$ & $c-S i$ & - & Linear & $20 \%$ \\
\hline [63] & & 17 & $38.50 \%$ & c-Si & 50 & Linear & $8.50 \%$ \\
\hline [48] & & 37 & $58 \%$ & c-Si & 65 & Linear & $11 \%$ \\
\hline [85] & & 200 & - & 3-junction & 60 & Point & $41.5 \%$ \\
\hline [91] & & 208.6 & - & InGaP/InGaAs/Ge & 105 & Point & $39 \%$ \\
\hline [86] & & 400 & - & $\begin{array}{l}\text { First: MJ } \\
\text { (Ge/InGaAs/InGaP) } \\
\text { Second: mono-Si \& } \\
\text { GaAs }\end{array}$ & 70 & Point & $\begin{array}{l}30 \% \\
27 \%\end{array}$ \\
\hline [89] & & 500 & $60 \%$ & MJPV & 100 & Point & $20 \%$ \\
\hline$[97,98]$ & & $132-795$ & $53 \%$ & 2-junction (GaAs) & - & Point & $24 \%$ \\
\hline [88] & & 629 & $70 \%$ & MJPV & - & Point & $20 \%$ \\
\hline
\end{tabular}


The cell temperature and electrical efficiency of the reported studies are ranged based on their concentration ratio and denoted with their single-/multi-junction semiconductor materials, as shown in Fig. 14. Clearly, the electrical efficiency reduces with an increase in the cell temperature, especially for single-junction materials where there is a high series resistance with increasing cell temperature. These results are as expected because increasing the concentration ratio raises the cell temperature, thereby increasing the heat dissipation, which results in a drop in the electrical efficiency. In addition, the electrical and thermal efficiencies have shown an inverse relationship for different CPVTs configurations, considering only the experimental studies where system details are fully reported, as in Fig.

10 15.

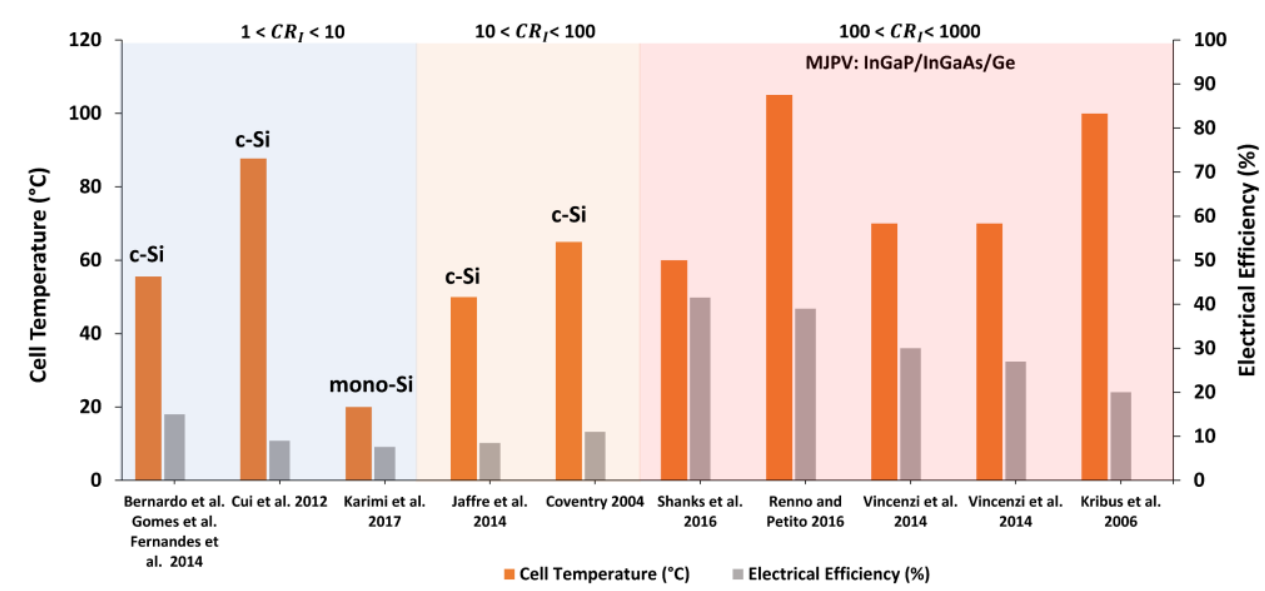

Fig. 14. The cell temperature and electrical efficiency for the reported CPVT studies and classified based on their level of 13

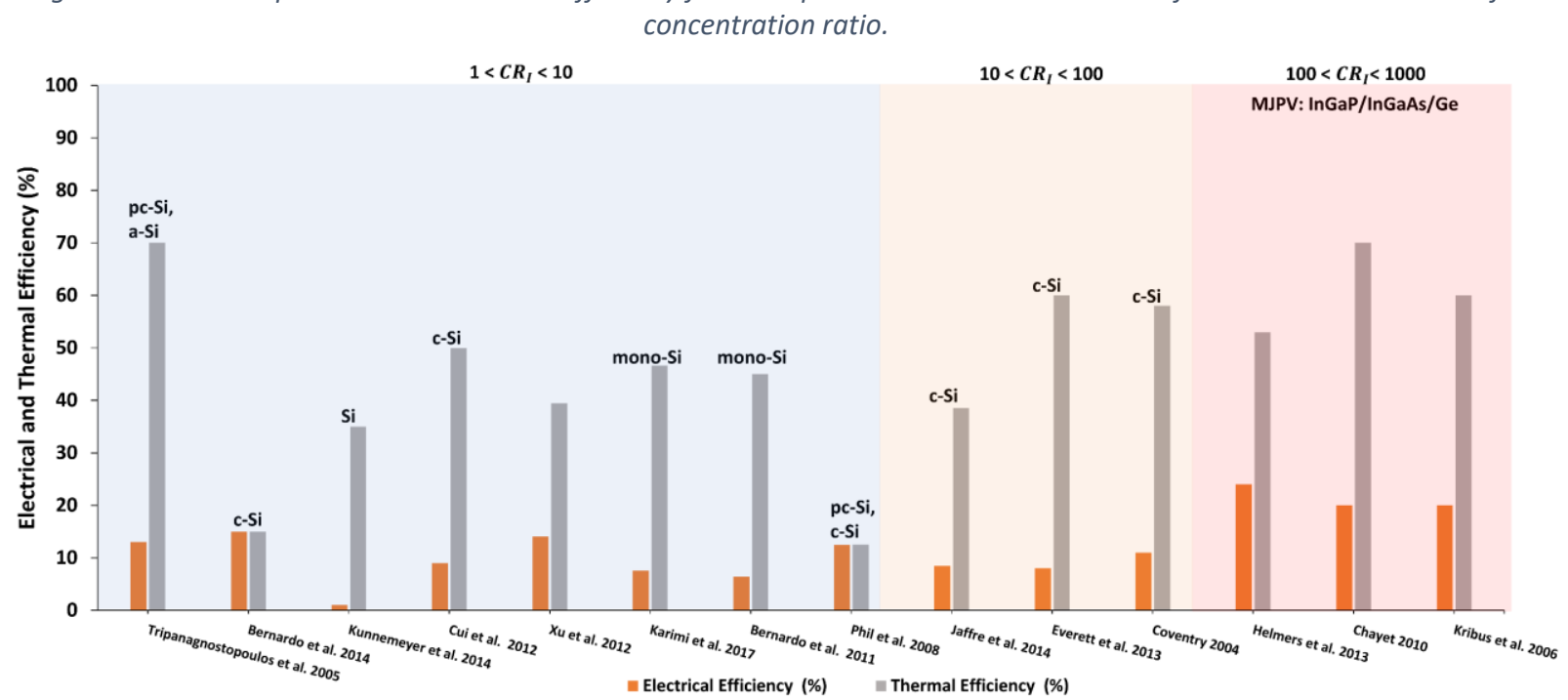


Novel optical configurations of CPVT systems are proposed to reach a high level of concentration ratio, at which the system cost is reduced, and the system progression is enhanced. Further, increasing the system efficiency by means of diminishing the volume, weight, and the manufacturing cost of the system reduces the overall system cost. A CPVT system with a high concentration ratio allows the increase in the cell conversion efficiency up to a concentration factor beyond which the cell conversion efficiency reduces, while producing more power and more cost-effectively. To illustrate this, the MJPV AzurSpace (Model $3 \mathrm{C} 44-3 \times 3 \mathrm{~mm}^{2}$ ) has a maximum cell conversion efficiency of $44 \%$ at 250 suns, after which the cell conversion efficiency reduces to $43.9 \%$ at 500 suns and $42.9 \%$ at 1000 suns in measurement conditions of $1.5 \mathrm{AM}-1000 \mathrm{~W} / \mathrm{m}^{2}, \mathrm{~T}=25^{\circ} \mathrm{C}$ [99]. The relationship between the system's initial cost as a power-related cost and the level of the concentration ratio in the range of 300-2000 suns for two system efficiencies is shown in Fig. 16.

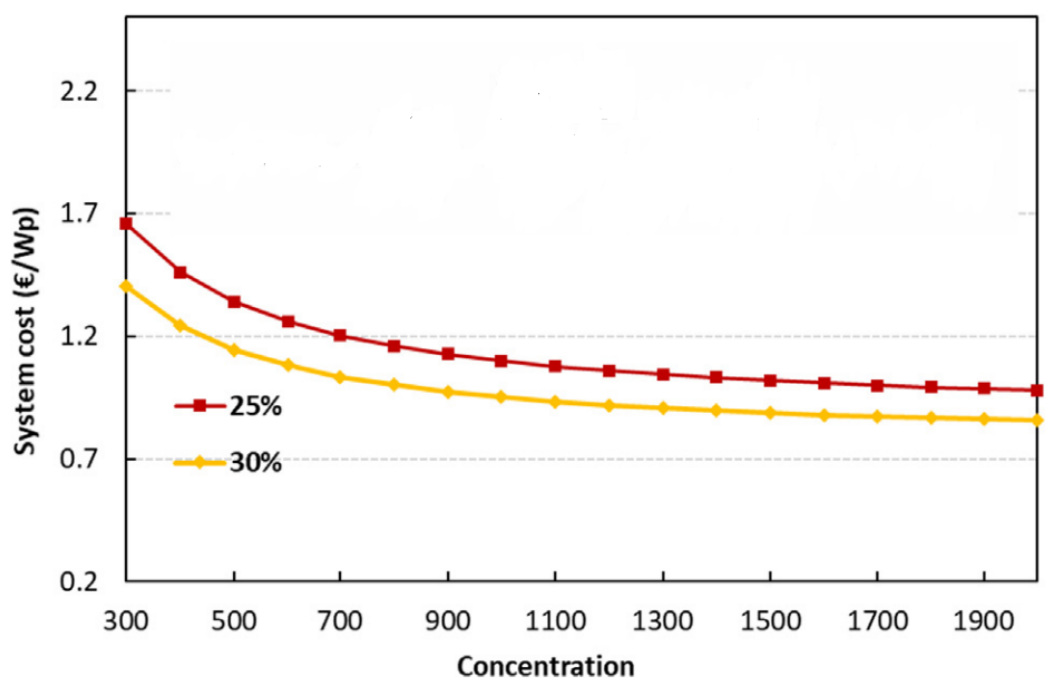

Fig. 16. System cost as a power with concentration ratio $[40,100]$.

Choosing a high-performance PV cell is not the best metric for selection. Costeffectiveness is one key approach for developing a high concentration CPVT system. For a high concentration ratio, multi-junction and non-silicon based solar cells are preferable due to their high performance under elevated operating temperatures. In contrast, for low concentration ratios, single-junction silicon-based solar cells are preferred due to their costeffectiveness and ready availability. Yazawa and Shakouri [101] studied theoretically the installation cost of CPVT systems per unit area with concentration ratios up to 1000 suns. They found that the cost of the PV material diminishes while the cost of the optics dominates at concentration ratios above 100 suns, without considering the cost of the mechanical complexity, as shown in Fig. 17. 


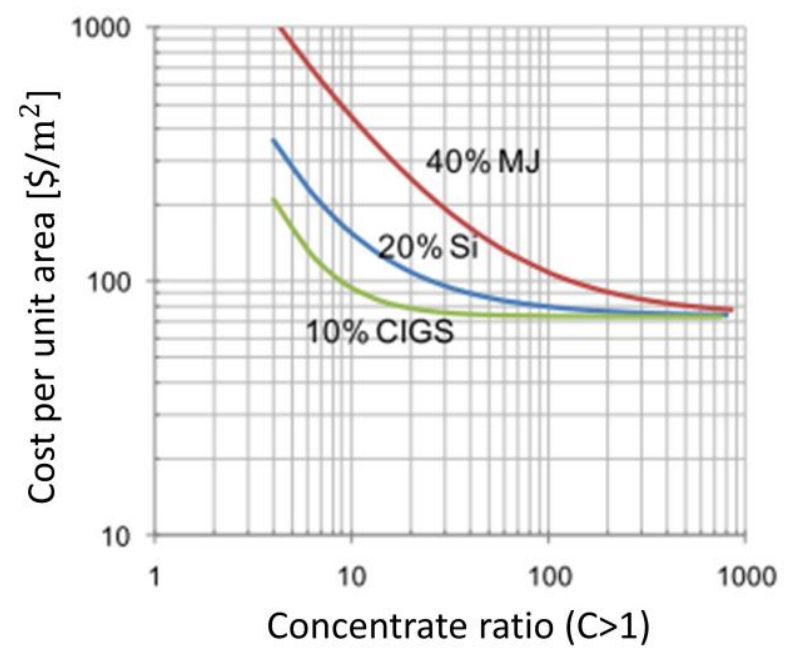

Fig. 17. Installation cost per unit of overall system [101].

Although MJPV cells have the highest efficiency in respect of the solar concentration, the market demand for them is not high due to their high production cost and to MJPV constituents being less available. MJPV cells are currently economically feasible only if the concentration ratio is sufficient to minimize the cell area and offset its initial cost [102]. Research and development for MJPVs to reduce the payback period and maximize the net present value (NPV) are important for operation under high concentration ratios. Comparison of the performance of single- dual-, and triple-junction solar cells versus concentration ratios ranging from 1-10000 suns is shown in Fig. 18. At certain concentration ratios, the PV cells reach their highest efficiency [103]. The peak efficiency occurs when the series resistance effects of the subcells dominate due to an increase in the current in accordance with the concentration ratio (as discussed in section 2). For selection of the MJPV type, the MJPV cell with a slight drop in efficiency after reaching the peak efficiency is more advantageous as, during real-time operation, the PV cell is not subject to a uniform concentration ratio, resulting in a localized hotspot. Moreover, the dual-junction cell has a smooth drop in efficiency, indicating that this type will have better efficiency in different concentrator modules close to 1000 suns.

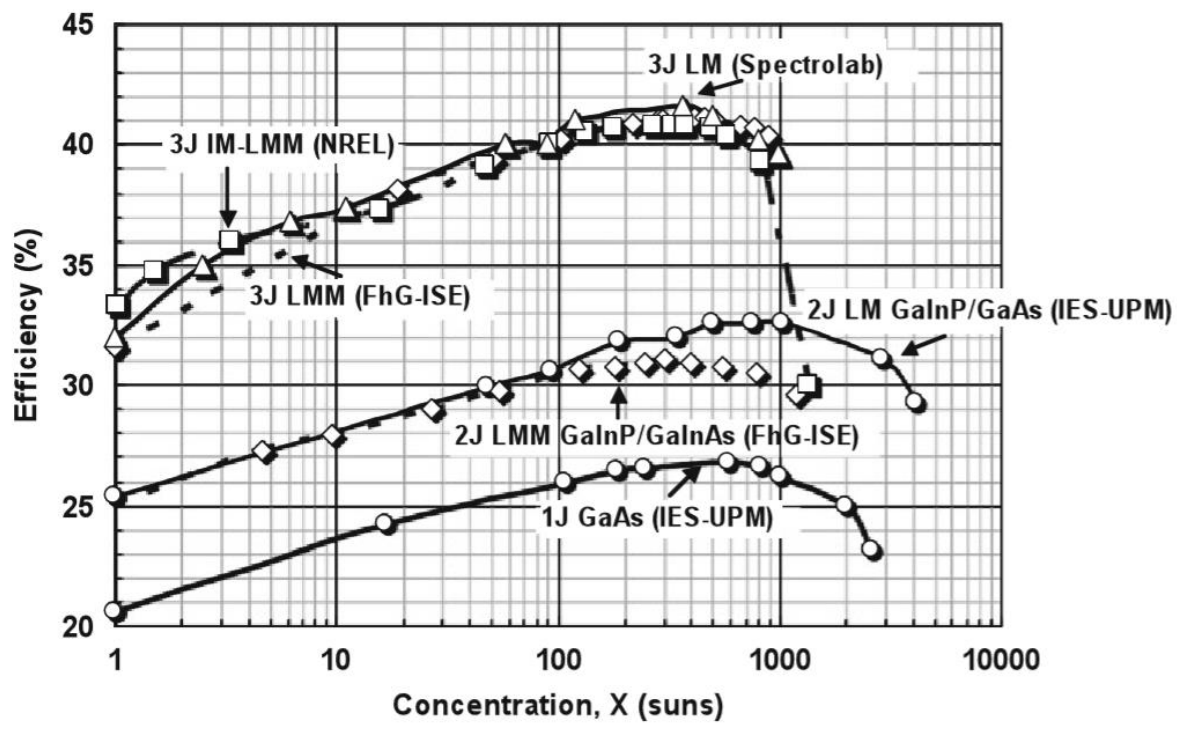


Concentrating sunrays to generate solar power is potentially more cost-effective, but it relies on the cost of the optical concentrators. The concentrators' price is still the main issue and it has been reported that the price of solar concentrators is between $\$ 150-\$ 250 / \mathrm{m}^{2}$, which is about half the total cost of installing a concentrated solar power (CSP) plant [104]. This issue is exaggerated by incorporating multiple optical interfaces to attain a high concentration factor. Although the CPVT is area-efficient and this results in less overall system cost (i.e., fewer PV materials), a vast number of large-scale solar PV deployments are required in a desert region, such as Saudi Arabia, Australia, and North Africa, where the value of land is dramatically low[105]. Thus, the highest efficiency CPVT does not convert into economic impact because the land cost is depressed. Because CPVT systems utilize an optical device to intensify direct solar radiation, the CPVT system's electrical and thermal output is maximized at the price of not only the optical device but also by incorporating a tracking system, MJPV cells, and an appropriate cooling mechanism. These associated components can result in an expensive CPVT system in comparison to the conventional solar PV panel. Micro-tracking technology is suggested to be subordinate to the CPVT system but it might be costcompetitive with solar PVs. However, the progression in CPVT system is not expedited in the same manner as solar PV, resulting in more profitability than the CPVT on the utility scale[106,107].

The cost of solar PV has not only competed with the CPV and CSP systems but also with the least fossil fuel cost, due to its ongoing technological development[108]. The use of concentrated solar technologies has expanded while their cost continues to fall [106]. For example, the cost of utility-scale solar PV has fallen from $\$ 0.378 / \mathrm{kWh}$ to $\$ 0.043 / \mathrm{kWh}$ with $89 \%$ of cost reduction, while CSP's price has decreased from $\$ 0.344 / \mathrm{kWh}$ to $\$ 0.095 / \mathrm{kWh}$ with $72 \%$ of cost reduction for the period between 2010 and 2020 [109]. The CPV system has also had a much lower cost in 2010 of $\$ 0.13 / \mathrm{kWh}$ in comparison to both solar PV and CSP and the price kept gradually decreasing until it reached $\$ 0.082 / \mathrm{kWh}$ with falling percent of $60 \%$ not less than the solar PV, as in Fig. 19 [110]. To put this in the context of technological progression, the amount of installed CSP $(5.5 \mathrm{GW})$ in 2018 was accomplished by solar PV in 2005. The solar PV cost reduction is set to continue beyond 2020 and it will offer less expensive electricity cost than the least fossil fuel cost. In 2020, CSP electricity offers a price between $\$ 0.06$ to $\$ 0.10 / \mathrm{kWh}$ range, while Solar PV provides a price of less than $\$ 0.048 / \mathrm{kWh}$. The cause of the highest cost reduction for the solar PV system in comparison to the CPV and CSP systems is the drop in the silicon module prices from $\$ 2 / \mathrm{W}$ to just over $\$ 0.20 / \mathrm{W}$ during the 2010s [111]. In contrast, concentrated solar technology could further reduce costs in view of developing cheaper optical materials with higher performance, and considering the induced high temperature on optics and solar cells [112]. 


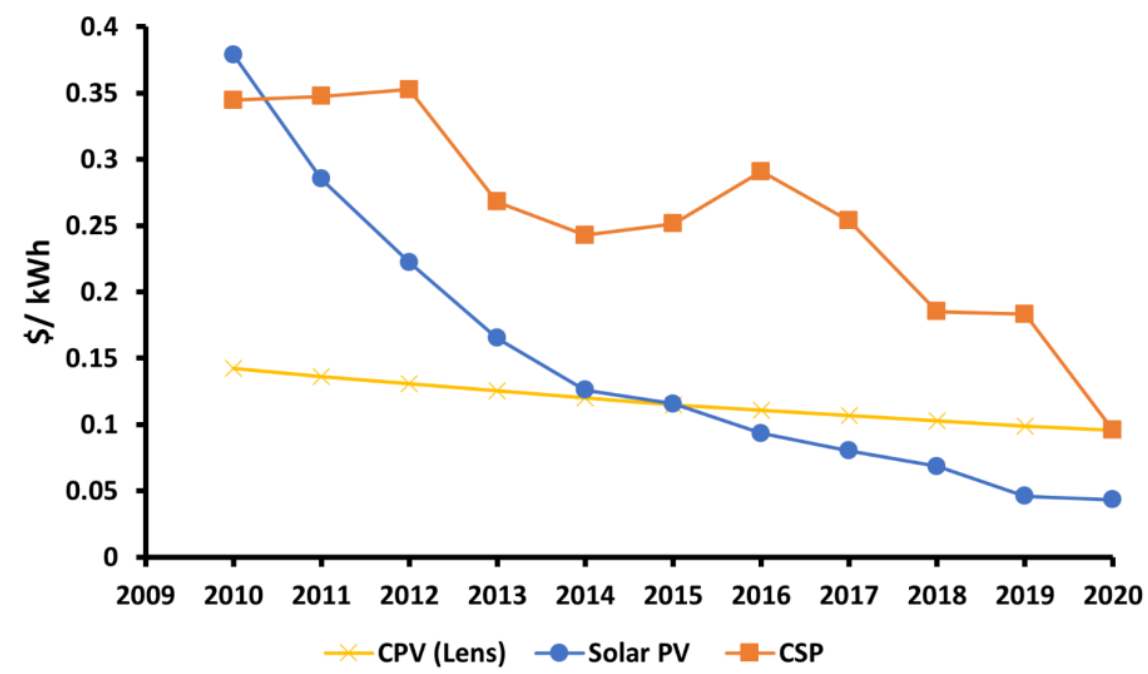

Fig. 19 The levelized cost of electricity $(\$ / k W h)$ for concentrated photovoltaic (CPV), Concentrated Solar Power (CSP), and
Solar PV plants for completed projects $[109,110]$.

\section{Future work}

Advances in CPVT research with the objective of reaching the highest concentration ratios are ongoing in order to achieve high thermal and electrical efficiencies. To do so, a range of high efficiency solar cell architectures along with novel optical configurations are needed. From this literature review, the key methods and techniques that need to be applied more consistently to improve CPVT performance and design have been identified as:

- Testing of the CPVT module's stability for accelerated aging when CPVT components are exposed to different outdoor climates and subjected to the worst-case operating conditions.

- Thermal cycling to assess the thermal deformation of all CPVT components where the thermal load varies from day to night and seasonally.

These measures will help solve the challenge of designing CPVT and PV cells with higher tolerances for elevated temperatures at high and ultrahigh concentration ratios.

\section{Conclusion}

In this review, a thorough analysis has been presented of the effect of temperature on CPVT solar cells and optics. The low resistance of multi-junction solar cells at $80^{\circ} \mathrm{C}$ allows higher concentration ratios to be accepted in comparison to single-junction solar cells. Intermetallic and monolithic multi-junction configurations, in particular, are effective and are readily available but with limitations. An intermetallic connection for each subcell results in maximum efficiency at the price of:

- Using a different substrate for every subcell

- Using antireflective coating for every subcell

- Additional thermal losses

- Complexity in the mechanical design and electrical connection

The monolithic multi-junction is dependent on the following factors for compatibility:

- Semiconductor materials need to be structurally compatible

- Compatible materials are required for electro-optical interconnection 
- Current matching, since the subcell design is in one stack

Common techniques for thermally managing the cell include spectral decomposition where only the photons in a range compatible with the cell are transmitted through the system. As is already known, the thermal receiver component needs to have a high thermal conductivity to conduct heat to the consecutive component. The thermal conductivity of the heat spreader, being centered between the PV cell and cooling mechanism, also needs to be as high as possible to ensure a high thermal utilization afterwards. Post-illumination techniques with a focal point and line have proven their capability to thermally manage the solar cell temperature within safe operating conditions under concentration ratios up to 10000 suns.

The optical concentrator is the key element to amplify the solar irradiance and concentrate it onto small-sized cells. Increasing the concentration ratio comes at the price of large optical areas or minimizing the receiver area, resulting in high extraction and generation of both thermal and electrical energies, respectively. At low levels of concentration ratio, a CPVT system receiver absorbs both direct and diffuse solar irradiance. At higher ranges of concentration ratio, the optics are subjected to higher temperatures, where the working temperature and thermal expansion coefficient of the optics, especially the secondary/homogenizer, need to be thoroughly investigated to avoid thermomechanical stresses. It is clear that boosting the concentration ratio above 100 suns increases the efficiencies and reduces the cost per unit area of the CPVT system. Still, more research and development is required to push performance/cost benefits at $>1000$ suns.

\section{Acknowledgment}

Mr Mussad Alzahrani would like to duly acknowledge the financial support from the Saudi Arabia Culture Bureau in the United Kingdom.

\section{Annex}

The data in Fig. 5 is derived from Table 6, which shows the limited efficiency for ideal bandgap energy under no concentration. Red and black lines represent two semiconductor material sets tested at the AM 1.5D spectrum and ideal blackbody spectrum, respectively. 
Table 6 Number of junctions with their semiconductor materials.

\begin{tabular}{|c|c|c|}
\hline $\begin{array}{c}\begin{array}{c}\text { Number } \\
\text { of } \\
\text { junctions }\end{array} \\
\end{array}$ & Red line (AM 1.5D spectrum) & Black line (ideal blackbody spectrum) \\
\hline 1 & $\mathrm{c}-\mathrm{Si}$ & $\mathrm{c}-\mathrm{Si}$ \\
\hline 2 & $\beta$-FeSi2/a-Si & $\beta$-FeSi2/a-Si \\
\hline 3 & $\mathrm{Ge} / \mathrm{c}-\mathrm{Si} / \mathrm{a}-\mathrm{Si}$ & $\beta$-FeSi2/Cu2ZnSn/Cu2O \\
\hline 4 & Ge/c-Si/a-Si/GaP & Ge/c-Si/Cu2ZnSn/ZnP2 \\
\hline 5 & Ge/c-Si/Cu2ZnSn/a-Si/GaP & Ge/c-Si/Cu2ZnSn/a-SiC/GaP \\
\hline 6 & CuFeS2/ $\beta$-FeSi2/c-Si/a-SiGe:H/Cu2O/3C-SiC & CuFeS2/ $\beta$-FeSi2/c-Si/a-SiGe:H/Cu2O/3C-SiC \\
\hline 7 & Ge/ $\beta$-FeSi2/c-Si/Cu2ZnSn/a-Si/ZnP2/CuAIS2 & CuFeS2/ $\beta$-FeSi2/c-Si/Cu2ZnSn/a-Si/ZnP2/CuAIS2 \\
\hline 8 & CuFeS2/Ge/ $\beta$-FeSi2/c-Si/Cu2ZnSn/a-Si/Cu2O/CuAIS3 & CuFeS2/Ge/ $\beta$-FeSi2/c-Si/Cu2ZnSn/a-Si/ZnP2/CuAIS2 \\
\hline
\end{tabular}

2 The data in Fig. 6 is derived from Table 7, which shows the semiconductor materials and their 3 concentration ratio for theoretical and experimental studies.

4 Table 7 semiconductor materials, study method, and their concentration ratio of theoretical and experimental CPVT studies.

\begin{tabular}{|c|c|c|c|}
\hline Reference & Method & Cell materials & $\begin{array}{c}\text { Concentration ratio } \\
\text { (CR) }\end{array}$ \\
\hline \multirow{2}{*}[54]{} & \multirow{2}{*}{ Experimental } & $\mathrm{p}-\mathrm{Si}$ & \multirow{2}{*}{1.35} \\
\hline & & $\mathrm{a}-\mathrm{Si}$ & \\
\hline [41] & Experimental & $\mathrm{Si}$ & 1.41 \\
\hline [36] & Experimental & c-Si & 1.5 \\
\hline [47] & Experimental & $\mathrm{Si}$ & 1.5 \\
\hline$[52]$ & Theoretical \& experimental & $\mathrm{c}-\mathrm{Si}$ & 1.5 \\
\hline [13] & Theoretical \& experimental & $\mathrm{Si}$ & 1.6 \\
\hline$[94]$ & Experimental & $\mathrm{c}-\mathrm{Si}$ & 1.86 \\
\hline [113] & Theoretical & $\mathrm{p}-\mathrm{Si}$ & 2 \\
\hline [114] & Experimental & $\mathrm{a}-\mathrm{Si}$ & 2.22 \\
\hline$[75]$ & Experimental & mono-Si & 4 \\
\hline [38] & Experimental & mono-Si & 5.85 \\
\hline \multirow{2}{*}[62]{} & \multirow{2}{*}{ Theoretical } & \multirow{2}{*}{ c-Si } & 1.5 \\
\hline & & & 3 \\
\hline [53] & Experimental & mono-Si & 3.5 \\
\hline \multirow{2}{*}{ [96] } & \multirow{2}{*}{ Theoretical \& experimental } & $\mathrm{c}-\mathrm{Si}$ & 5.81 \\
\hline & & pc-Si & 7.1 \\
\hline$[2]$ & Experimental & $\mathrm{c}-\mathrm{Si}$ & 6 \\
\hline [49] & Experimental & mono-Si & 7.8 \\
\hline \multirow{2}{*}{ [115] } & \multirow{2}{*}{ Theoretical \& experimental } & \multirow{2}{*}{ c-Si } & 7 \\
\hline & & & 10 \\
\hline \multirow{2}{*}{ [116] } & \multirow{2}{*}{ Theoretical } & $\mathrm{c}-\mathrm{Si}$ & \multirow{2}{*}{10} \\
\hline & & InGaP/InGaAs/Ge & \\
\hline \multirow{5}{*}[46]{} & \multirow{5}{*}{ Experimental } & super cell/GaAs & \multirow{5}{*}{10.27} \\
\hline & & mono-Si & \\
\hline & & poly-Si & \\
\hline & & super-Si & \\
\hline & & GaAs & \\
\hline [34] & Theoretical \& experimental & $\mathrm{Si}$ & 11.1 \\
\hline [117] & Theoretical & $\mathrm{Si}$ & 13.5 \\
\hline$[51]$ & Experimental & mono-Si & 14.5 \\
\hline
\end{tabular}




\begin{tabular}{|c|c|c|c|}
\hline [59] & Experimental & c-Si & 15 \\
\hline$[63]$ & Experimental & c-Si & 17 \\
\hline \multirow{3}{*}{ [118] } & \multirow{3}{*}{ Experimental } & customized-Si & \multirow{3}{*}{20} \\
\hline & & GaAs & \\
\hline & & $\begin{array}{l}\text { MJPV (super } \\
\text { cell/GaAs/Si) }\end{array}$ & \\
\hline$[58]$ & Experimental & mono-Si & 25 \\
\hline [119] & Theoretical & $\mathrm{c}-\mathrm{Si}$ & 25 \\
\hline [120] & Theoretical & $\mathrm{c}-\mathrm{Si}$ & 28.4 \\
\hline [79] & Experimental & $\mathrm{c}-\mathrm{Si}$ & 30 \\
\hline [121] & Experimental & $\mathrm{Si}$ & 30 \\
\hline$[48]$ & Experimental & $\mathrm{c}-\mathrm{Si}$ & 37 \\
\hline$[60]$ & Theoretical & $\mathrm{Si}$ & 80 \\
\hline$[40]$ & Theoretical & $\mathrm{Si}$ & 100 \\
\hline \multirow{5}{*}{ [122] } & \multirow{5}{*}{ Theoretical } & Ge & \multirow{5}{*}{200} \\
\hline & & $\mathrm{Si}$ & \\
\hline & & InGaP & \\
\hline & & CdTe & \\
\hline & & InGaAS & \\
\hline [91] & Theoretical \& experimental & $\begin{array}{c}\text { MJPV } \\
(\operatorname{InGaP} / \operatorname{InGaAs} / \mathrm{Ge})\end{array}$ & 208.6 \\
\hline \multirow{3}{*}[86]{} & \multirow{3}{*}{ Theoretical \& experimental } & $\begin{array}{c}\text { MJPV } \\
\text { (Ge/InGaAs/InGaP) }\end{array}$ & \multirow{3}{*}{400} \\
\hline & & mono-Si & \\
\hline & & GaAs & \\
\hline [97] & Theoretical & $\begin{array}{c}\text { MJPV } \\
(\mathrm{Ge} / \ln G a A s / \ln G a P)\end{array}$ & 500 \\
\hline [89] & Experimental & $\begin{array}{c}\text { MJPV } \\
(\mathrm{Ge} / \mathrm{InGaAs} / \operatorname{lnGaP})\end{array}$ & 500 \\
\hline [123] & Theoretical & $\mathrm{c}-\mathrm{Si}$ & 500 \\
\hline$[90]$ & Experimental & $\begin{array}{c}\text { MJPV } \\
(\operatorname{lnGaP} / \operatorname{lnGaAs} / G e)\end{array}$ & 550 \\
\hline [88] & Experimental & $\begin{array}{c}\text { MJPV } \\
(\operatorname{lnGaP} / \operatorname{lnGaAs} / \mathrm{Ge})\end{array}$ & 629 \\
\hline [98] & Theoretical \& experimental & 2-junction (GaAs) & 795 \\
\hline
\end{tabular}




\section{References}

[1] H. Baig, N. Sarmah, K.C. Heasman, T.K. Mallick, Numerical modelling and experimental validation of a low concentrating photovoltaic system, Solar Energy Materials and Solar Cells. (2013). doi:10.1016/j.solmat.2013.01.035.

[2] D. Chemisana, T.K. Mallick, Building integrated concentrating solar systems, Solar Energy Sciences and Engineering Applications. (2013) 545-587. doi:10.1201/b15507.

[3] A. Zahedi, Review of modelling details in relation to low-concentration solar concentrating photovoltaic, Renewable and Sustainable Energy Reviews. 15 (2011) 1609-1614. doi:10.1016/j.rser.2010.11.051.

[4] L. Micheli, N. Sarmah, X. Luo, K.S. Reddy, T.K. Mallick, Opportunities and challenges in micro- and nano-technologies for concentrating photovoltaic cooling : A review, Renewable and Sustainable Energy Reviews. 20 (2013) 595-610. doi:10.1016/j.rser.2012.11.051.

[5] G. Almonacid, P.G. Vidal, E. Mu, High Concentrator PhotoVoltaics efficiencies: Present status and forecast, Renewable and Sustainable Energy Reviews. 15 (2015) 1810-1815. doi:https://doi.org/10.1016/j.rser.2010.11.046.

[6] W.T. Xie, Y.J. Dai, R.Z. Wang, K. Sumathy, Concentrated solar energy applications using Fresnel lenses : A review, Renewable and Sustainable Energy Reviews. 15 (2011) 2588-2606. doi:10.1016/j.rser.2011.03.031.

[7] D. Chemisana, Building Integrated Concentrating Photovoltaics : A review, Renewable and Sustainable Energy Reviews. 15 (2011) 603-611. doi:10.1016/j.rser.2010.07.017.

[8] A. Makki, S. Omer, H. Sabir, Advancements in hybrid photovoltaic systems for enhanced solar cells performance, Renewable and Sustainable Energy Reviews. 41 (2015) 658-684. doi:10.1016/j.rser.2014.08.069.

[9] R.R. Avezov, J.S. Akhatov, N.R. Avezova, A Review on Photovoltaic-Thermal (PV-T) Air and Water Collectors1, Applied Solar Energy. 47 (2011) 169-183. doi:10.3103/S0003701X11030042.

[10] B. Singh, M.Y. Othman, A review on photovoltaic thermal collectors, Journal of Renewable and Sustainable Energy. 062702 (2009). doi:10.1063/1.3266963.

[11] O.Z. Sharaf, M.F. Orhan, Concentrated photovoltaic thermal (CPVT) solar collector systems: Part I - Fundamentals, design considerations and current technologies, Renewable and Sustainable Energy Reviews. 50 (2015) 1500-1565. doi:10.1016/j.rser.2015.05.036.

[12] O.Z. Sharaf, M.F. Orhann, Concentrated photovoltaic thermal (CPVT) solar collector systems: Part II - Implemented systems, performance assessment, and future directions, Renewable and Sustainable Energy Reviews. 50 (2015) 1566-1633. doi:10.1016/j.rser.2014.07.215.

[13] R. Daneshazarian, E. Cuce, P.M. Cuce, F. Sher, Concentrating photovoltaic thermal (CPVT) collectors and systems: Theory, performance assessment and applications, Renewable and Sustainable Energy Reviews. 81 (2018) 473-492. doi:10.1016/j.rser.2017.08.013.

[14] A. Mojiri, R. Taylor, E. Thomsen, G. Rosengarten, Spectral beam splitting for ef fi cient conversion of solar energy - A review, Renewable and Sustainable Energy Reviews. 28 (2013) 654-663. doi:10.1016/j.rser.2013.08.026.

[15] X. Ju, C. Xu, X. Han, X. Du, G. Wei, Y. Yang, A review of the concentrated photovoltaic/thermal (CPVT) hybrid solar systems based on the spectral beam splitting technology, Applied Energy. 187 (2017) 534-563. 
doi:10.1016/j.apenergy.2016.11.087.

[16] N.L.A. Chan, N.J. Ekins-Daukes, J.G.J. Adams, M.P. Lumb, M. Gonzalez, P.P. Jenkins, I. Vurgaftman, J.R. Meyer, R.J. Walters, Optimal bandgap combinations-does material quality matter, IEEE Journal of Photovoltaics. 2 (2012) 202-208. doi:10.1109/JPHOTOV.2011.2180513.

[17] L.C. Herst, N. Ekins-Daukes, Fundamental losses in solar cells, Progress in Photovoltaics: Research and Applications. 19 (2010) 286-293. doi:10.1002/pip.

[18] R. Chenni, M. Makhlouf, T. Kerbache, A. Bouzid, A detailed modeling method for photovoltaic cells, Energy. 32 (2007) 1724-1730. doi:10.1016/j.energy.2006.12.006.

[19] S.P. Philipps, F. Dimroth, A.W. Bett, High-Efficiency III-V Multijunction Solar Cells, in: McEvoy's Handbook of Photovoltaics, Elsevier, 2018: pp. 439-472. doi:10.1016/B9780-12-809921-6.00012-4.

[20] M. Bercx, R. Saniz, B. Partoens, D. Lamoen, Exceeding the Shockley-Queisser Limit Within the Detailed Balance Framework, in: Many-Body Approaches at Different Scales, Springer International Publishing, Cham, 2018: pp. 177-184. doi:10.1007/9783-319-72374-7_15.

[21] A. Polman, M. Knight, E.C. Garnett, B. Ehrler, W.C. Sinke, Photovoltaic materials: Present efficiencies and future challenges, Science. 352 (2016) 10-12. doi:10.1126/science.aad4424.

[22] M.A. Green, K. Emery, Y. Hishikawa, W. Warta, E.D. Dunlop, Solar cell efficiency tables (version 41), Progress in Photovoltaics: Research and Applications. 21 (2013) 1-11. doi:10.1002/pip.2352.

[23] A. Martí, G.L. Araújo, Limiting efficiencies for photovoltaic energy conversion in multigap systems, Solar Energy Materials and Solar Cells. 43 (1996) 203-222. doi:10.1016/0927-0248(96)00015-3.

[24] Hugo Doeleman, Limiting and realistic efficiencies of multi-junction solar cells, FOM Institute AMOLF, 2012. doi:https://pdfs.semanticscholar.org/b083/753c6d04cd2af20379de785e7a71f2e885b 6.pdf?_ga=2.85718480.83315905.1592515641-107842748.1553173981.

[25] W. Hu, Y. Harada, A. Hasegawa, T. Inoue, O. Kojima, T. Kita, Intermediate band photovoltaics based on interband-intraband transitions using $\operatorname{In} 0.53 \mathrm{Ga} 0.47 \mathrm{As} / \mathrm{InP}$ superlattice, Progress in Photovoltaics: Research and Applications. 20 (2011) n/a-n/a. doi:10.1002/pip.1208.

[26] A. Luque, S. Hegedus, Handbook of Photovoltaic Science, Springer, 2003. https://scholar.google.com/scholar_lookup?title=Concentrator photovoltaics\&author=A.L. Luque\&publication_year=2007.

[27] H. Baig, N. Sellami, D. Chemisana, J. Rosell, T.K. Mallick, Performance analysis of a dielectric based 3D building integrated concentrating photovoltaic system, Solar Energy. 103 (2014) 525-540. doi:10.1016/j.solener.2014.03.002.

[28] K. Shanks, J.P. Ferrer-rodriguez, E.F. Fernández, F. Almonacid, A > 3000 suns high concentrator photovoltaic design based on multiple Fresnel lens primaries focusing to one central solar cell, Solar Energy. 169 (2018) 457-467. doi:10.1016/j.solener.2018.05.016.

[29] A. Yavrian, S. Tremblay, M. Levesque, R. Gilbert, How to increase the efficiency of a high concentrating PV (HCPV) by increasing the acceptance angle to $\pm 3.2^{\circ}$, in: AIP Conference Proceedings, 2013: pp. 197-200. doi:10.1063/1.4822230.

[30] L. Micheli, N. Sarmah, E.F. Fernandez, K.S. Reddy, T.K. Mallick, Technical issues and 
challenges in the fabrication of a 144-Cell 500x Concentrating Photovoltaic receiver, 2014 IEEE 40th Photovoltaic Specialist Conference, PVSC 2014. (2014) 2921-2925. doi:10.1109/PVSC.2014.6925543.

[31] Azur Space Solar Power GMBH, Enhanced Fresnel Assembly - EFA Type: 3C42A - with $10 \times 10 \mathrm{~mm}^{2}$ CPV TJ Solar Cell Application: Concentrating Photovoltaic (CPV) Modules, (2014) 0-4. http://www.azurspace.com/images/products/DB_3987-0000_3C42_AzurDesign_EFA_10x10_2014-03-27.pdf.

[32] L. Mabille, C. Mangeant, M. Baudrit, Development of CPV solar receiver based on insulated metal substrate (IMS): Comparison with receiver based on the direct bonded copper substrate (DBC) - A reliability study, AIP Conference Proceedings. 1477 (2012) 289-293. doi:10.1063/1.4753888.

[33] L. Micheli, S. Senthilarasu, K.S. Reddy, T.K. Mallick, Applicability of silicon microfinned heat sinks for $500 \times$ concentrating photovoltaics systems, Journal of Materials Science. 50 (2015) 5378-5388. doi:10.1007/s10853-015-9065-2.

[34] M. Iba, J.I. Rosell, X. Vallverdu, Design and simulation of a low concentrating photovoltaic / thermal system, 46 (2005) 3034-3046. doi:10.1016/j.enconman.2005.01.012.

[35] S. Chow, C.E. Valdivia, J.F. Wheeldon, R. Ares, O.J. Arenas, V. Aimez, D. McMeekin, S. Fafard, K. Hinzer, Thermal test and simulation of alumina receiver with high efficiency multi-junction solar cell for concentrator systems, Photonics North 2010. 7750 (2010) 775035. doi:10.1117/12.872894.

[36] J. Gomes, L. Diwan, R. Bernardo, B. Karlsson, Minimizing the Impact of Shading at Oblique Solar Angles in a Fully Enclosed Asymmetric Concentrating PVT Collector, Energy Procedia. 57 (2014) 2176-2185. doi:10.1016/j.egypro.2014.10.184.

[37] L. Guiqiang, P. Gang, Y. Su, Z. Xi, J. Jie, Preliminary study based on building-integrated compound parabolic concentrators ( CPC ) PV / thermal technology, (2012). doi:10.1016/j.egypro.2011.12.887.

[38] F. Karimi, H. Xu, Z. Wang, J. Chen, M. Yang, Experimental study of a concentrated PV/T system using linear Fresnel lens, Energy. 123 (2017) 402-412. doi:10.1016/j.energy.2017.02.028.

[39] F. Gualdi, O. Arenas, A. Vossier, A. Dollet, V. Aimez, R. Arès, Determining passive cooling limits in CPV using an analytical thermal model, AIP Conference Proceedings. 1556 (2013) 10-13. doi:10.1063/1.4822187.

[40] A. Valera, E.F. Fernández, P.M. Rodrigo, F. Almonacid, Feasibility of flat-plate heatsinks using microscale solar cells up to 10,000 suns concentrations, Solar Energy. 181 (2019) 361-371. doi:10.1016/j.solener.2019.02.013.

[41] A.H.A. Al-Waeli, K. Sopian, M.T. Chaichan, H.A. Kazem, H.A. Hasan, A.N. Al-Shamani, An experimental investigation of SiC nanofluid as a base-fluid for a photovoltaic thermal PV/T system, Energy Conversion and Management. 142 (2017) 547-558. doi:10.1016/j.enconman.2017.03.076.

[42] E. Bellos, C. Tzivanidis, Investigation of a nanofluid-based concentrating thermal photovoltaic with a parabolic reflector, Energy Conversion and Management. 180 (2019) 171-182. doi:10.1016/j.enconman.2018.11.008.

[43] S.K. Verma, A.K. Tiwari, S. Tiwari, D.S. Chauhan, Performance analysis of hybrid nanofluids in flat plate solar collector as an advanced working fluid, Solar Energy. 167 (2018) 231-241. doi:10.1016/j.solener.2018.04.017.

[44] S. Iranmanesh, H.C. Ong, B.C. Ang, E. Sadeghinezhad, A. Esmaeilzadeh, M. Mehrali, 
Thermal performance enhancement of an evacuated tube solar collector using graphene nanoplatelets nanofluid, Journal of Cleaner Production. 162 (2017) 121129. doi:10.1016/j.jclepro.2017.05.175.

[45] S. Lee, S.U.-S. Choi, S. Li, J.A. Eastman, Measuring Thermal Conductivity of Fluids Containing Oxide Nanoparticles, Journal of Heat Transfer. 121 (1999) 280-289. doi:10.1115/1.2825978.

[46] L. Xu, X. Ji, F. Yin, M. Li, G.L. Li, The performance analysis of the Trough Concentrating Solar Photovoltaic/Thermal system, Energy Conversion and Management. 52 (2011) 2378-2383. doi:10.1016/j.enconman.2010.12.039.

[47] B. Ricardo, H. Davidsson, G. Niko, J. Gomes, G. Christian, C. Luis, M. Chabu, B. Karlsson, Measurements of the Electrical Incidence Angle Modifiers of an Asymmetrical Photovoltaic/Thermal Compound Parabolic Concentrating-Collector, Engineering. 05 (2013) 37-43. doi:10.4236/eng.2013.51B007.

[48] J.S. Coventry, Performance of a concentrating photovoltaic/thermal solar collector, Solar Energy. 78 (2005) 211-222. doi:10.1016/j.solener.2004.03.014.

[49] L.R. Bernardo, B. Perers, H. Håkansson, B. Karlsson, Performance evaluation of low concentrating photovoltaic/thermal systems: A case study from Sweden, Solar Energy. 85 (2011) 1499-1510. doi:10.1016/j.solener.2011.04.006.

[50] R. Künnemeyer, T.N. Anderson, M. Duke, J.K. Carson, Performance of a V-trough photovoltaic/thermal concentrator, Solar Energy. 101 (2014) 19-27. doi:10.1016/j.solener.2013.11.024.

[51] M. Chaabane, W. Charfi, H. Mhiri, P. Bournot, Performance evaluation of concentrating solar photovoltaic and photovoltaic/thermal systems, Solar Energy. 98 (2013) 315-321. doi:10.1016/j.solener.2013.09.029.

[52] L.T. Kostic, T.M. Pavlovic, Z.T. Pavlovic, Influence of reflectance from flat aluminum concentrators on energy efficiency of PV/Thermal collector, Applied Energy. 87 (2010) 410-416. doi:10.1016/j.apenergy.2009.05.038.

[53] J. Nilsson, H. Håkansson, B. Karlsson, Electrical and thermal characterization of a PVCPC hybrid, Solar Energy. 81 (2007) 917-928. doi:10.1016/j.solener.2006.11.005.

[54] Y. Tripanagnostopoulos, T. Nousia, M. Souliotis, P. Yianoulis, Hybrid photovoltaic/thermal solar systems, Solar Energy. 72 (2002) 217-234. doi:10.1016/S0038-092X(01)00096-2.

[55] G. Xu, X. Zhang, S. Deng, Experimental study on the operating characteristics of a novel low-concentrating solar photovoltaic/thermal integrated heat pump water heating system, Applied Thermal Engineering. 31 (2011) 3689-3695. doi:10.1016/j.applthermaleng.2011.01.030.

[56] H. Davidsson, B. Perers, B. Karlsson, Performance of a multifunctional PV/T hybrid solar window, Solar Energy. 84 (2010) 365-372. doi:10.1016/j.solener.2009.11.006.

[57] G.K. Chinyama, A. Roos, B. Karlsson, Stability of antireflection coatings for large area glazing, Solar Energy. 50 (1993) 105-111. doi:10.1016/0038-092X(93)90081-X.

[58] P.J. Sonneveld, G.L.A.M. Swinkels, J. Campen, B.A.J. van Tuijl, H.J.J. Janssen, G.P.A. Bot, Performance results of a solar greenhouse combining electrical and thermal energy production, Biosystems Engineering. 106 (2010) 48-57. doi:10.1016/j.biosystemseng.2010.02.003.

[59] V. Everett, J. Harvey, S. Surve, E. Thomsen, D. Walter, M. Vivar, A. Blakers, A. Tanner, $M$. Greaves, P. Le Leivre, Evaluation of electrical and thermal performance of a linear hybrid CPV-T micro-concentrator system, AIP Conference Proceedings. 1407 (2011) 
262-265. doi:10.1063/1.3658340.

[60] S.-L. Jiang, P. Hu, S.-P. Mo, Z.-S. Chen, Modeling for Two-Stage Dish Concentrating Spectral Beam Splitting Photovoltaic/Thermal System, in: 2009 Asia-Pacific Power and Energy Engineering Conference, IEEE, 2009: pp. 1-4. doi:10.1109/APPEEC.2009.4918499.

[61] R. Liu, An Overview of Aluminum Protective Coating Properties and Treatments, OPTI, The University of ARIZONA. (2009).

[62] B.M. Ziapour, V. Palideh, F. Mokhtari, Performance improvement of the finned passive PVT system using reflectors like removable insulation covers, Applied Thermal Engineering. 94 (2016) 341-349. doi:10.1016/j.applthermaleng.2015.10.143.

[63] D. Jaffré, F. Gualdi, M. Sicre, R. El Ouamari, A. Dollet, G. Baud, D. Martin, Design and characterization of a curved linear fresnel lens concentrating photovoltaic and thermal system, AIP Conference Proceedings. 1616 (2014) 173-176. doi:10.1063/1.4897054.

[64] G. Soni, S. Srivastava, P. Soni, P. Kalotra, Y.K. Vijay, Optical, mechanical and structural properties of PMMA/SiO 2 nanocomposite thin films, Materials Research Express. 5 (2018) 015302. doi:10.1088/2053-1591/aaa0f7.

[65] Polymethylmethacrylate (PMMA), (n.d.). http://www.goodfellow.com/A/Polymethylmethacrylate.html.

[66] J.J. Valencia, Thermophysical Properties, Corporation, Concurrent Technologies. 15 (2008) 468-481. doi:10.1361/asmhba0005240.

[67] L.T. Kostić, T.M. Pavlović, Z.T. Pavlović, Optimal design of orientation of PV/T collector with reflectors, Applied Energy. 87 (2010) 3023-3029. doi:10.1016/j.apenergy.2010.02.015.

[68] J. González-Benito, E. Castillo, J.F. Cruz-Caldito, Determination of the linear coefficient of thermal expansion in polymer films at the nanoscale: influence of the composition of EVA copolymers and the molecular weight of PMMA, Physical Chemistry Chemical Physics. 17 (2015) 18495-18500. doi:10.1039/C5CP02384J.

[69] H.-S. E., S. F.H., R. V., S. M., Degradation mechanisms of aluminium diffusion coatings on $12 \%$ chromium steels under elevated temperature erosion - oxidation conditions, Materials at High Temperatures. 23 (2006) 1-11. doi:10.1179/mht.2006.001.

[70] Properties and Selection: Nonferrous Alloys and Special-Purpose Materials, 10th Ed, ASM International, 1990. doi:10.31399/asm.hb.v02.9781627081627.

[71] Joseph R. Davis, Aluminum and Aluminum Alloys, ASM International, 1990. https://books.google.com.sa/books?id=Lskj5k3PSIcC\&pg=PA674\&dq=aluminum+foil+ working+temperature+260+-+510\&hl=en\&sa=X\&ved=0ahUKEwid7frLw4zqAhXN5AKHVaHBDoQ6AEIJzAA\#v=onepage \&q=aluminum foil working temperature 260 $510 \& f=f a l s e$.

[72] John M. (Tim) Holt, Structural Alloys Handbook, Technical Ed; C. Y. Ho, Ed., CINDAS/Purdue University, 1996.

[73] Y. Goueffon, C. Mabru, M. Labarrère, L. Arurault, C. Tonon, P. Guigue, Investigations into the coefficient of thermal expansion of porous films prepared on AA7175 T7351 by anodizing in sulphuric acid electrolyte, Surface and Coatings Technology. 205 (2010) 2643-2648. doi:10.1016/j.surfcoat.2010.10.026.

[74] J. Lee, Y. Kim, U. Jung, W. Chung, Thermal conductivity of anodized aluminum oxide layer: The effect of electrolyte and temperature, Materials Chemistry and Physics. 141 (2013) 680-685. doi:10.1016/j.matchemphys.2013.05.058. 
[75] M. Brogren, P. Nostell, B. Karlsson, Optical efficiency of a PV-thermal hybrid CPC module for high latitudes, Solar Energy. 69 (2001) 173-185. doi:10.1016/S0038092X(01)00066-4.

[76] Alucoil Grupo Aliberico, Aluminum Mirror - TECHNICAL-DETAILS-ALMIRR, n.d.

[77] P. Patnaik, Handbook of Inorganic Chemicals, McGraw-Hill, 2002.

[78] J.W. Liu, Z.H. Rao, S.M. Liao, H.L. Tsai, Numerical investigation of weld pool behaviors and ripple formation for a moving GTA welding under pulsed currents, International Journal of Heat and Mass Transfer. 91 (2015) 990-1000. doi:10.1016/j.ijheatmasstransfer.2015.08.046.

[79] M. Vivar, V. Everett, M. Fuentes, A. Blakers, A. Tanner, P. Le Lievre, M. Greaves, Initial field performance of a hybrid CPV-T microconcentrator system, Progress in Photovoltaics: Research and Applications. 21 (2013) 1659-1671. doi:10.1002/pip.2229.

[80] A. Czanderna, K. Masterson, T.M. Thomas, Silver/Glass Mirrors for Solar Thermal Systems, Solar Energy Research Institute, United States, 1985.

[81] THERMALLYBROKEN STEEL USA, Galvanized Steel and Stainless Steel Material Data Sheet, 2004. https://thermallybrokensteelusa.com/wpcontent/uploads/2015/10/Material_Data_Sheet-Thermally-Broken-Steel-USA.pdf.

[82] I. Al Siyabi, K. Shanks, S. Khanna, T.K. Mallick, S. Sundaram, Evaluation of concentrating photovoltaic performance under different homogeniser materials, Materials Letters. 241 (2019) 219-222. doi:10.1016/j.matlet.2019.01.129.

[83] J. Sarwar, T. Shrouf, K.E. Kakosimos, Characterization of thermal performance and optical properties of a material under concentrated radiation using a high flux solar simulator, in: AIP Conference Proceedings, 2017: p. 160025. doi:10.1063/1.4984559.

[84] P. McVey-White, P. Besson, M. Baudrit, H.P. Schriemer, K. Hinzer, Effects of lens temperature on irradiance profile and chromatic aberration for CPV optics, in: AIP Conference Proceedings, 2016: p. 040004. doi:10.1063/1.4962081.

[85] K. Shanks, H. Baig, N.P. Singh, S. Senthilarasu, K.S. Reddy, T.K. Mallick, Prototype fabrication and experimental investigation of a conjugate refractive reflective homogeniser in a cassegrain concentrator, Solar Energy. 142 (2017) 97-108. doi:10.1016/j.solener.2016.11.038.

[86] D. Vincenzi, S. Baricordi, S. Calabrese, M. Musio, A. Damiano, A cassegrain concentrator photovoltaic system: Comparison between dichroic and multijunction photovoltaic configurations, IECON Proceedings (Industrial Electronics Conference). (2014) 1900-1905. doi:10.1109/IECON.2014.7048761.

[87] A. Colozza, R. Macosko, C. Castle, K. Sacksteder, N. Suzuki, J. Mulherin, Cassigranian Solar Concentrator for ISRU Material Processing, in: 50th AIAA Aerospace Sciences Meeting Including the New Horizons Forum and Aerospace Exposition, American Institute of Aeronautics and Astronautics, Reston, Virigina, 2012: pp. 1-15. doi:10.2514/6.2012-637.

[88] H. Chayet, I. Lozovsky, O. Kost, R. Loeckenhoff, K.-D. Rasch, A.W. Bett, R.D. McConnell, G. Sala, F. Dimroth, HIGH EFFICIENCY, LOW COST PARABOLIC DISH SYSTEM FOR COGENERATION OF ELECTRICITY AND HEAT, in: AIP Conference Proceedings, 2010: pp. 175-178. doi:10.1063/1.3509183.

[89] A. Kribus, D. Kaftori, G. Mittelman, A. Hirshfeld, Y. Flitsanov, A. Dayan, A miniature concentrating photovoltaic and thermal system, Energy Conversion and Management. 47 (2006) 3582-3590. doi:10.1016/j.enconman.2006.01.013. 
[90] P.J. Pérez-Higueras, F.M. Almonacid, P.M. Rodrigo, E.F. Fernández, Optimum sizing of the inverter for maximizing the energy yield in state-of-the-art high-concentrator photovoltaic systems, Solar Energy. 171 (2018) 728-739. doi:10.1016/j.solener.2018.07.013.

[91] C. Renno, F. Petito, Experimental and theoretical model of a concentrating photovoltaic and thermal system, Energy Conversion and Management. 126 (2016) 516-525. doi:10.1016/j.enconman.2016.08.027.

[92] N. Rathore, N.L. Panwar, F. Yettou, A Comprehensive review on different types of solar photovoltaic cells and their applications, International Journal of Ambient Energy. 0 (2019) 1-48. doi:10.1080/01430750.2019.1592774.

[93] M. Kouhnavard, S. Ikeda, N.A. Ludin, N.B. Ahmad Khairudin, B.V. Ghaffari, M.A. MatTeridi, M.A. Ibrahim, S. Sepeai, K. Sopian, A review of semiconductor materials as sensitizers for quantum dot-sensitized solar cells, Renewable and Sustainable Energy Reviews. 37 (2014) 397-407. doi:10.1016/j.rser.2014.05.023.

[94] W. Cui, L. Zhao, W. Wu, K. Wang, T.C. Jen, Energy efficiency of a quasi cpc concentrating solar PV/T system, in: ASME International Mechanical Engineering Congress and Exposition, Proceedings (IMECE), 2010: pp. 1071-1076. doi:10.1115/IMECE2010-38341.

[95] Y. Xu, C.Y. Wang, Y.M. Hua, Y.M. Zhang, Studies on a Low Concentration Photovoltaic/Thermal System with Constant Volume Refrigeration, Key Engineering Materials. 517 (2012) 776-783. doi:10.4028/www.scientific.net/KEM.517.776.

[96] E. Pihl, C. Thapper, H.J. Nilsson, Evaluation of the concentrating PVT systems MaReCo and Solar8, 2006. http://lup.lub.lu.se/record/1027919.

[97] H. Helmers, A.W. Bett, J. Parisi, C. Agert, Modeling of concentrating photovoltaic and thermal systems, Progress in Photovoltaics: Research and Applications. 22 (2014) 427-439. doi:10.1002/pip.2287.

[98] H. Helmers, A. Boos, F. Jetter, A. Heimsath, M. Wiesenfarth, A.W. Bett, F. Dimroth, S. Kurtz, G. Sala, A.W. Bett, Outdoor Test Setup for Concentrating Photovoltaic and Thermal (CPVT) Systems, in: AIP Conference Proceedings, 2011: pp. 175-179. doi:10.1063/1.3658320.

[99] M. Data, T. Average, E. Data, Concentrator Triple Junction Solar Cell Cell Type : 3C44C$3 \times 3 \mathrm{~mm} 2$ Azur Space, (2012) 3-6.

http://www.azurspace.com/images/products/0004357-0001_3C44_AzurDesign_3x3.pdf.

[100] P. Fernández, E.F., Almonacid, F., Rodrigo, P.M., Pérez-Higueras, CPV Systems., in: McEvoy's Handbook Photovoltic, 2017: pp. 931-985.

[101] K. Yazawa, A. Shakouri, Material Optimization for Concentrated Solar Photovoltaic and Thermal Co-Generation, in: ASME 2011 Pacific Rim Technical Conference and Exhibition on Packaging and Integration of Electronic and Photonic Systems, MEMS and NEMS: Volume 1, ASMEDC, 2011: pp. 733-739. doi:10.1115/IPACK2011-52190.

[102] A. Lopez, A. Vega, A. Lopez, Next Generation of Photovoltaics, Springer Berlin Heidelberg, Berlin, Heidelberg, 2012. doi:10.1007/978-3-642-23369-2.

[103] C. Algora, I. Rey-Stolle, Chapter 2 The Interest and Potential of Ultra-High Concentration. Next Generation of Photovoltaics: New Concept, Springer Berlin Heidelberg, Berlin, Heidelberg, 2012. doi:10.1007/978-3-642-23369-2.

[104] Low-Cost, Lightweight Solar Concentrator (Fact Sheet), Golden, CO (United States), 2012. doi:10.2172/1053327. 
[105] D.J. Wright, S. Badruddin, C. Robertson-Gillis, Micro-Tracked CPV Can Be Cost Competitive With PV in Behind-The-Meter Applications With Demand Charges, Frontiers in Energy Research. 6 (2018). doi:10.3389/fenrg.2018.00097.

[106] J.E. Haysom, O. Jafarieh, H. Anis, K. Hinzer, D. Wright, Learning curve analysis of concentrated photovoltaic systems, Progress in Photovoltaics: Research and Applications. 23 (2015) 1678-1686. doi:10.1002/pip.2567.

[107] E. Gil, M. Martinez, O. de la Rubia, Operation and maintenance results from ISFOC CPV plants, in: 2017: p. 020006. doi:10.1063/1.5001405.

[108] A. Kalair, N. Abas, M.S. Saleem, A.R. Kalair, N. Khan, Role of energy storage systems in energy transition from fossil fuels to renewables, Energy Storage. (2020). doi:10.1002/est2.135.

[109] I.R.E. Agency, Renewable Power Generation Costs in 2018, 2018. https://www.irena.org//media/Files/IRENA/Agency/Publication/2018/Jan/IRENA_2017_Power_Costs_2018.p df.

[110] Chapter 5 Energy. Optics and Photonics, National Academies Press, Washington, D.C., 2013. doi:10.17226/13491.

[111] D. Feldman, E. O'Shaughnessy, R. Margolis, Solar Industry Update Q3/Q4 2019, NREL Presentation. (2020) 1-83. https://www.nrel.gov/docs/fy20osti/76158.pdf.

[112] Overview and Summary of America's Energy Future: Technology and Transformation, National Academies Press, Washington, D.C., 2010. doi:10.17226/12943.

[113] M. Hedayatizadeh, Y. Ajabshirchi, F. Sarhaddi, A. Safavinejad, S. Farahat, H. Chaji, Thermal and Electrical Assessment of an Integrated Solar Photovoltaic Thermal (PV/T) Water Collector Equipped with a Compound Parabolic Concentrator (CPC), International Journal of Green Energy. 10 (2013) 494-522. doi:10.1080/15435075.2012.678524.

[114] H. Matsuoka, T. Tamura, Design and Evaluation of Thermal-photovoltaic Hybrid Power Generation Module for More Efficient Use of Solar Energy, NIT DOCOMO Technical Journal. 12 (2010) 61-67. https://www.nttdocomo.co.jp/english/binary/pdf/corporate/technology/rd/technical journal/bn/vol12_3/vol12_3_061en.pdf.

[115] D. Chemisana, M. Ibáñez, J.I. Rosell, Characterization of a photovoltaic-thermal module for Fresnel linear concentrator, Energy Conversion and Management. 52 (2011) 3234-3240. doi:10.1016/j.enconman.2011.04.008.

[116] F. Calise, L. Vanoli, Parabolic Trough Photovoltaic/Thermal Collectors: Design and Simulation Model, Energies. 5 (2012) 4186-4208. doi:10.3390/en5104186.

[117] N. Ahmad, T. Ijiro, N. Yamada, T. Kawaguchi, T. Maemura, H. Ohashi, Optical design of wavelength selective CPVT system with 3D/2D hybrid concentration, in: R. Winston, J.M. Gordon (Eds.), 2012: p. 84850T. doi:10.1117/12.929395.

[118] M. Li, X. Ji, G. Li, S. Wei, Y. Li, F. Shi, Performance study of solar cell arrays based on a Trough Concentrating Photovoltaic/Thermal system, Applied Energy. 88 (2011) 32183227. doi:10.1016/j.apenergy.2011.03.030.

[119] J.S. Coventry, E. Franklin, A. Blakers, Thermal and electrical performance of a concentrating PV/Thermal collector: results from the ANU CHAPS collector, ANZSES Solar Energy Conference. (2004).

[120] P. Hu, Q. Zhang, Y. Liu, C. Sheng, X. Cheng, Z. Chen, Optical analysis of a hybrid solar concentrating Photovoltaic/Thermal (CPV/T) system with beam splitting technique, 
Science China Technological Sciences. 56 (2013) 1387-1394. doi:10.1007/s11431013-5209-2.

[121] P.J. Sonneveld, G.L.A.M. Swinkels, B.A.J. van Tuijl, H.J.J. Janssen, J. Campen, G.P.A. Bot, Performance of a concentrated photovoltaic energy system with static linear Fresnel lenses, Solar Energy. 85 (2011) 432-442. doi:10.1016/j.solener.2010.12.001.

[122] T.P. Otanicar, R.A. Taylor, C. Telang, Photovoltaic/thermal system performance utilizing thin film and nanoparticle dispersion based optical filters, Journal of Renewable and Sustainable Energy. 5 (2013) 033124. doi:10.1063/1.4811095.

[123] A. Segal, M. Epstein, A. Yogev, Hybrid concentrated photovoltaic and thermal power conversion at different spectral bands, Solar Energy. 76 (2004) 591-601. doi:10.1016/j.solener.2003.12.002. 